\title{
Matematik ve Fen Bilgisi Öğretmeni Adaylarının İntegral Konusundaki Yeterliklerinin Tanısal Değerlendirilmesi
}

\section{Okan KUZU*}

Öz: $\mathrm{Bu}$ çalışmada, matematik ve fen bilgisi öğretmeni adayları için integral konusunun anlaşılmasına yönelik gerekli olan dört kritik yeterlik belirlenmiş ve adayların bu yeterliklere sahip olma olasılıkları bilişsel tanı modellerinden log-lineer cognitive diagnostic model kullanılarak araştırılmıştır. Bu bağlamda, bu dört kritik yeterliği ölçen ve 25 çoktan seçmeli sorudan oluşan “İntegral Kazanım Yeterlik Testi” hazırlanmış ve 2018-2019 eğitim-öğretim yılında toplam 190 matematik ve fen bilgisi öğretmeni adayına uygulanmıştır. Yüksek maddeyeterlik ayırt edicilik indeksine sahip olan bu testin her bir yeterliği sırasıyla .99, .98, .99, ve .95 güvenirlikle ölçtüğü belirlenmiştir. Test maddelerinin ölçtüğü yeterliğe dair uzman görüşleri alınmış ve Lawshe tekniği ile her bir maddenin hangi yeterliği veya yeterlikleri ölçtüğü belirlenmiştir. Dört kritik yeterliği ölçen bu maddelerin dağılımı için ise Q-matris oluşturulmuş ve MPlus 6.12 programı yardımıyla log-lineer cognitive diagnostic model kullanılarak her bir adayın ilgili yeterliğe bireysel olarak sahip olma olasılıkları hesaplanmıştır. Yapılan analizler sonucunda, matematik öğretmeni adaylarının çok yüksek olasılıkla integral kavramını açıklayabildiği (\%99) ve integral alma yöntemlerini bildiği (\%88) görülmüş; kavramsal bilgi düzeylerinin işlemsel bilgi düzeylerine oranla daha yüksek olduğu belirlenmiştir. Fen bilgisi öğretmeni adaylarının ise yüksek olasılıkla belirsiz integral hesabı yapabildiği (.76), çok yüksek olasılıkla da belirli integralleri kullanarak uygulamalar yapabildiği (\%87) görülmüş; işlemsel bilgi düzeylerinin kavramsal bilgi düzeylerine oranla daha yüksek olduğu ortaya çıkmıştır.

Anahtar Kelimeler: Bilişsel Tanı Modelleri, İntegral, Yeterlik, Kavramsal Bilgi, İşlemsel Bilgi.

\footnotetext{
*Dr. Öğr. Üyesi, Kırşehir Ahi Evran Üniversitesi, Eğitim Fakültesi, Matematik ve Fen Bilimleri Eğitimi Bölümü, Email:okan.kuzu@ahievran.edu.tr, Orcid No: 0000-0003-2466-4701.

${ }^{* *} \mathrm{Bu}$ araştırma için Kırşehir Ahi Evran Üniversitesi Sosyal ve Beşeri Bilimleri Etik Kurulu Başkanlığında (01/07/2020 tarih ve 2020/02 sayısı) etik izin alınmıştır.
}

\begin{tabular}{lll}
\hline Gönderim:12.10.2020 & Kabul:09.01.2021 & Yayın:15.01.2021 \\
\hline
\end{tabular}


Diagnostic Assessment of Preservice Mathematics and Science Teachers' Attributes on Integral

Abstract: In this study, four critical attributes required for understanding the integral concept were determined and the probability of preservice mathematics and science teachers having these attributes were investigated using the log-linear cognitive diagnostic model, one of the cognitive diagnosis models. In this context, the "Integral Attribute Research Test", which measures these four critical attributes and consists of 25 multiple-choice questions, was prepared and also administered to a total of 190 preservice mathematics and science teachers in the 2018-2019 academic year. It was determined that this test, which has a high item-attribute discrimination indices, measures each attributes with .99, .98, .99, and .95 reliability respectively. Expert opinions were taken for measured competence by test items and, with the Lawshe technique, it was determined that each item measured which attribute or attributes. For the distribution of these items that measure four critical attributes, a Q-matrix was created and the probability of each preservice teacher having the relevant attribute individually was calculated using the log-linear cognitive diagnostic model with the MPlus 6.12 program. As a result of the analysis, it was seen that the preservice mathematics teacher could explain the integral concept with a very high probability (99\%) and knew the methods of integration (88\%). Moreover, it was determined that their conceptual knowledge levels were higher than the procedural knowledge levels for the preservice mathematics teachers. It was revealed that preservice science teachers could calculate indefinite integrals with high probability (.76\%), make applications by using definite integrals with very high probability (87\%); and their procedural knowledge levels were higher than conceptual knowledge levels.

Keywords: Cognitive Diagnosis Models, Integral, Attribute, Conceptual Knowledge, Procedural Knowledge.

\section{Giriş}

Teoremlerin ve kuralların sorgulayıcı şekilde açıklanarak mantık ve küme teorisi ile temellendirildiği analiz bilimi (Sevimli, 2013) matematiğin hemen her dalı ile ilişki içerisinde yer almakta ve birçok disiplinin temelini oluşturmaktadır (Ergene, 2019). Eğitim öğretim süreci dikkate alındığında ise, ortaöğretimden lisansüstüne kadar her aşamada önemli bir yere sahip olan analiz bilimi üst düzey matematiksel becerileri içermekte ve öğrencilerin ileri düzeyde matematiksel düşünebilme becerilerini geliştirebilmektedir. Analiz biliminin limit, türev, integral gibi ileri düzey matematik konularını içerisinde barındırması ve öğrencilerdeki 
sorgulama, muhakeme ve matematiksel düşünme gibi becerileri geliştirmesi (Ergene, 2019; Konyalığ lu, Tortumlu, Kaplan, Işık ve Hızarc1, 2011) ise, analiz bilimin matematikte ne kadar önemli bir yere sahip olduğunun bir göstergesi olarak görülebilir.

Analiz biliminin temel kavramları arasında yer alan integral kavramının ters türev, eğri altında kalan alan, belirli bir aralıktaki toplam değişim gibi çeşitli anlamlar içermesi analizin diğer konuları ile yakından ilişkili olmasına neden olmakta ve matematik eğitimcilerinin dikkatlerini çekmektedir (Ergene, 2019). İntegralin, fizik, istatistik, mühendislik, mimarlık gibi diğer disiplinlerde de sıklıkla kullanılması ve endüstriyelden teknolojiye, bilgisayar sistemlerinden elektrik devrelerine birçok alanda yerinin olması yadsınamaz bir gerçektir. Yapılan çalışmalar (Delice ve Sevimli, 2011; Ergene, 2014; Ferrini-Mundy ve Graham, 1994; Kuzu, 2017; Orton, 1983; Rasslan ve Tall, 2002; Tall ve Vinner, 1981; Tatar, Okur ve Tuna, 2008; Wagner, 2016) incelendiğinde integralin anlaşılması güç kavramlar arasında yer aldığ1 ve uygulama alanlarında öğrencilerin zorlandığı görülmektedir. Gürbüz, Toprak, Yapıcı ve Doğan (2011) tarafından yapılan çalışmada ise integral kavramına yönelik öğrenci ve öğretmen görüşlerine yer verilmiş ve ortak yargı ile integralin öğrenilmesi ve öğretilmesi en güç konular arasında olduğu belirtilmiştir. Diğer taraftan, öğrenciler işlemsel bilgi düzeyindeki integral sorularında başarı gösterseler dahi bu bilgileri yorumlamada ve farklı bir bağlamda kullanmada zorluk yaşayabilecekleri (Camacho, Depool ve Santos-Trigo, 2004; Orton, 1983) ve integralin tanımını, anlamını, doğasını ve matematikteki yerini anlamlandırmada eksikliklere sahip olabilecekleri (Ergene, 2019) vurgulanmıştır.

Anlamanın doğasında yer alan kavramsal ve işlemsel bilgi için geçmişten günümüze çeşitli tanımlar ve açıklamalar ile karşılaşılabilmekte (Ayrıntılı bilgi için bkz. Yanık, 2016) ve kullanıldığı ortam, konu ve bağlama göre farklı anlamlara gelebilmektedir (Delice ve Sevimli, 2010). En genel haliyle kavramsal bilgi, kavram, prensipler ve tanımlar bilgisi olarak (Barody, Feil ve Johnson, 2007; Byrnes ve Wasik, 1991; Canobi, 2009; Rittle-Johnson, Siegler ve Alibali, 2001; Star, 2005, 2007) tanımlanırken; işlemsel bilgi, problem çözmede kullanılan işlem adımları ve algoritmaları içeren bilgi olarak adlandırılmaktadır (Reason, 2003; Star, 2005, 2007). Ayrıca, kavramsal bilgiye sahip bireyler, yaptı̆̆ı işlemlerin nedenlerini/niçinlerini açıklayabilmekte iken, işlemsel bilgiye sahip bireylerin yaptığı işlerin nedenlerini/niçinlerini açıklayamadıkları ve daha çok ezbere yöneldikleri görülmektedir (Reason, 2003). Skemp (1976) tarafindan yapılan çalışmada kavramsal ve işlemsel bilgi arasında hiyerarşik bir ilişkinin olduğu ve kavramsal bilginin işlemsel bilgiden daha önemli olduğu belirtilmiştir. Hiebert ve Lefevre (1986) yaptığı çalışmada ise, matematiksel bilginin içselleştirilmesi ve 
ilişkilendirilmesi ile oluşan kavramsal bilginin işlemsel bilgiye anlam kazandırdığını ve kavramsal bilginin olmadığı işlemsel bilginin matematik öğretiminin özüne aykırı olduğunu vurgulamıştır. Ayrıca, işlemsel bilgisinin ezberlenerek öğrenmeye uygun olduğunu ve anlamlandırılmadan ezberlenmiş bir bilginin ise başka durumlar için kullanılamayacağını; kavramsal bilgiye sahip olma durumunda ise kurallar, algoritmalar ve/veya işlemler arasında ilişki kurma düzeyinin artacağını ve öğrenilmesi gereken işlem sayısının azalacağını belirtmiştir (Hiebert ve Lefevre, 1986). Zaman içerisinde yapılan çalışmalar incelendiğinde, matematik öğretiminde her iki bilgi türüne de ihtiyaç duyulduğu ve birinin diğerinden daha önemli olmadığı belirtilmiştir (Carpenter, 1986; Ersoy, 2002; Kuzu, 2020a; Öçal, 2017; Yanık, 2016). Ayrıca, kavramsal ve işlemsel bilginin matematik öğretiminde ve problem çözme sürecinde birbiri ile ilişkilendirilerek kullanılmasının oldukça önemli olduğu ifade edilmiştir (Delice ve Sevimli, 2010; Kuzu, 2020b; Lesh \& Doerr, 2003; Öçal, 2017). Her ne kadar, önceki yıllarda işlemsel bilginin ezberlenerek öğrenildiği bir bilgi türü olduğu belirtilse de (Baroody, 2003; Reason, 2003), sonraki yıllarda yapılan çalışmalarda (Baroody, Feil ve Johnson, 2007) işlemsel bilginin ezberlenmiş işlem bilgisi olarak ifade edilmemesi gerektiği vurgulanmıştır. Yine geçmiş yıllarda işlemsel bilgi için problemin çözümü yapılamasa dahi, içerisindeki matematiksel ifadelerin ne anlama geldiğinin bilinmesi yeterli görülürken (Hiebert ve Lefevre, 1986), sonraki yıllarda bu problemin çözüm sürecinin de incelenmesi gerektiği belirtilmiştir (Rittle-Johnson ve Schneider, 2015). Kısacası, kavramsal bilginin ölçülmesinde genellikle bireyin ilgili kavramı tanımlaması ve açıklaması istenirken; işlemsel bilginin ölçülmesinde ise çoğunlukla verilen bir problemin çözülmesi istenerek sonucun ya da işlemin doğruluğuna bakılmaktadır (Rittle-Johnson ve Schneider, 2015).

Analiz derslerinde kavrama dayalı olarak kurallı öğrenmenin daha baskın olduğu ve hesap temelli yaklaşımların benimsendiği bilinmektedir (Sevimli, 2009). Oysaki öğrencilerin genelleme ve soyutlama yapabilmesini ortaya çıkarmak amacıyla kavramsal bilgiye de ağırlık verilmesi gerekmektedir (Bekdemir, 2012). Örneğin, analizini temel konuları arasında yer alan integralin öğrenciler tarafından ters türevi alınabilin fonksiyonların hesaplanmasında kullanılan algoritmalar olduğu bilinmekte ve bu algoritmaların anlamlandırılmasında eksikliklerinin olduğu görülmektedir (Camacho-Machin, Depool-Rivero ve Santos-Trigo, 2010). Hem kavramsal hem de işlemsel bilgi düzeyinde başarılı ve yetkin öğrencilerin yetiştirilmesi ise öğretim yöntemlerinin tercihi ile yakından ilişkilidir. Nitekim matematik, epistemoloji ve öğretim yöntem bilgisinden oluşan sacayağının dengeli ve sağlam kurulması oldukça önemlidir (Baki, 1997). 
Birbiri üzerine konumlandırılmış konulardan oluşan matematikte, bir konunun tam olarak anlamlandırılamaması ilişkili ya da devamı niteliğinde olan konuların öğreniminde güçlüklerin ortaya çıkmasına sebep olabilmektedir (Kuzu, 2017). Böylece öğrencilerin soyut düşünme ve problem çözme gibi üst düzey bilişsel becerilerdeki performansları da etkilenmektedir (Chappell ve Killpatrick, 2003; Hiebert ve Carpenter, 1992; Sevimli, 2013). Matematiksel bilgi ve becerilerin günlük hayata transfer edilmesi noktasında eksikliklerin olması anlamlı öğrenmenin oluşmasına ve öğrenci performanslarının artmasına olumsuz etki edebileceği (Kuzu, Çil ve Şimşek, 2019) göz önüne alındığında; integral kavramının anlamlandırılamaması beraberinde uzunluk, alan, hacim gibi gerçek hayata yönelik problemlerde güçlük yaşanmasına zemin hazırlayabilmektedir. Eğitim sistemi içerisinde integralin günlük uygulamalarının dikkate alınmaması ise öğrenciler tarafından hiçbir anlam ifade etmeyen, soyut, gereksiz ve ezberlenmesi gereken bir konu yığını olarak algılanmasına neden olmaktadır (Durmuş, 2004). İntegral konusunun geçmişten günümüze önemini korumas1 ve öğretim programlarında yerini alması öğrencilerin integral kavramına yönelik ne tür yeterliklerde eksikliklerinin olduğuna yönelik merak uyandırmaktadır. Öğrenme sürecinde karşılaşılan güçlüklerinin kaynağının bilinmesi ise güçlüklerin giderilmesi açısından gerekli olan önemli bir adım olarak bilinmektedir (Yetkin, 2003). Öğrenme güçlüğü ile matematik performansı arasında pozitif yönde anlamlı bir ilişkinin olduğu (Bender, 2014; Russell ve Ginsberg, 1984; Vukovic ve Siegel, 2010) ve öğrenci performanslarının araştırılması ile öğrencilerin akademik gelişimlerinin farkına varılacağı, daha nitelikli ve etkili öğretim yöntemleri kullanılacağı belirtilmektedir (Ginsburg, 1989; Smith ve Rivera, 1991).

Alanyazında integral konusundaki öğrenci performansları üzerine yapılan çalışmalar (örn., Aydın ve Önder, 2010; Dündar ve Y1lmaz, 2015; Karabey, 2011; Ramdani, Rohaeni ve Wachidah, 2019; Zakaria ve Salleh, 2015) incelendiğinde öğrenci performanslarının Klasik Test Kuramı (KTK) kullanarak ortalama ya da toplam skora dayalı şekilde araştırıldı̆̆ görülmektedir. Bu çalışmalarda, öğrencilerin aldıkları toplam puanların ortalaması alınarak öğrenci performansları hakkında değerlendirmeler yapılabilmektedir. Ortalama ya da toplam puan gibi tek bir puana dayalı değerlendirme yapılmasının çok detaylı bilgi veremediği belirtilmiş (Nichols, Chipman ve Brennan, 2012; Leighton ve Gierl, 2007) ve KTK'ya kıyasla daha güvenilir tahminler sunan (Templin ve Bradshaw, 2013), daha detaylı değerlendirmeye olanak tanıyan bilişsel tanı modelleri geliştirilmiştir (BTM) (Rupp, Templin ve Henson, 2010).

Tanısal sinıflandırma modelleri (Diagnostic Classification Models [DCM]) olarak da tanımlanan bilişsel tanı modelleri, katılımcıların ölçülmek istenilen yeterliğe hangi olasılıkla 
sahip olduklarını hesaplayarak bu yeterlikler hakkında eğitimcilere bilişsel geri bildirim sağlamakta ve katılımcıların bilişsel olarak güçlü ve zayıf yanlarıyla ilgili daha detaylı bilgi sunmaktadır. Son yıllarda, bilişsel tanı modelleri üzerine yapılan çalışmalar (örn., Arican, 2019; Arican ve Kuzu, 2020; Bradshaw, Izsak, Templin ve Jacobson, 2014; Choi, Lee ve Park, 2015; Dogan ve Tatsuoka, 2008; Im ve Park, 2010; Kuzu ve Arican, 2020; Lee, Park ve Taylan, 2011; Sen ve Arican, 2015) ile bireylerin çeşitli matematik konularından elde ettikleri sonuçlar hakkında tanılayıcı değerlendirmeler yapılmıştır. Bilişsel tanı modelleri telafi edici modeller, telafi edici olmayan modeller ve genel modeller olmak üzere üç kategoride toplanmaktadır (Ravand ve Robitzsch, 2015). Deterministic input, noisy-or-gate model (DINO) (Bkz. Templin ve Henson, 2006) ve compensatory reparameterized unified model (C-RUM) (Bkz. Hartz, 2002) telafi edici modellere örnek olarak verilebilir. Telafi edici olmayan modellere deterministic input, noisy-and-gate model (DINA) (Bkz. Junker ve Sijtsma, 2001) ve noncompensatory reparameterized unified model (NC-RUM) (Bkz. DiBello, Stout ve Roussos, 1995; Hartz, 2002) örnek verilebilir. Son olarak, hem telafi edici hem de telafi edici olmayan ilişkilere olanak tanıyan genel modellere ise general diagnostic model (GDM) (Bkz. von Davier, 2005), log-linear cognitive diagnostic model (LCDM) (Bkz. Henson, Templin, Willse, 2009) ve generalized deterministic input, noisy-and-gate model (G-DINA) (Bkz. de la Torre, 2011) örnek verilebilir. Genel modellerden biri olan LCDM, katılımcıların maddelere verdikleri yanıtları örtük sınıflara yerleştirebilir ve her bir yanıtın yeterlik etkisini madde parametrelerinin büyüklüğüne ve yönüne bağlı olarak modelleyerek yeterliklerin belirlenme sürecinde araştırmacılara esneklik sağlamaktadır (Bradshaw ve diğ., 2014).

Matematikte önemli bir yere sahip olan integral konusunun anlaşılması güç konular arasında yer alması yükseköğretim programlarında öğrenim gören matematik ve fen bilgisi öğretmeni adaylarının bu konuda yeterli olduklarına dair soru işaretleri oluşturmuş ve integral konusunun öğretiminde ve öğreniminde gerekli olan yeterlikler açısından adayların eksikliklerin olabileceğini düşündürmüştür. Bu sebeple, matematik ve fen bilgisi öğretmeni adayları için integral konusunun anlaşılmasına yönelik gerekli bazı kritik yeterlikler belirlenmiş ve adayların bu yeterliklere sahip olma olasılıkları LCDM kullanılarak aşağıdaki yer alan araştırma soruları kapsamında araştırılmıştır

1) Matematik ve Fen Bilgisi öğretmeni adaylarının integral konusundaki yeterliklere sahip olma olasılıkları ne düzeydedir?

2) Matematik ve Fen Bilgisi öğretmeni adaylarının integral konusundaki yeterliklere sahip olma olasılıkları bölümlerine göre farklılık göstermekte midir? 
3) Matematik ve Fen Bilgisi öğretmeni adaylarının integral konusundaki yeterliklere sahip olma olasılıkları cinsiyetlerine göre farklılık göstermekte midir?

4) Matematik ve Fen Bilgisi öğretmeni adaylarının integral konusundaki yeterliklere sahip olma olasılıkları sınıf düzeylerine göre farklılık göstermekte midir?

5) Matematik ve Fen Bilgisi öğretmeni adaylarının integral konusundaki yeterliklere sahip olma olasılıklarının kendi aralarında anlamlı bir ilişski var mıdır?

\section{Yöntem}

\section{Araştırmanın Modeli}

İntegral konusunun anlaşılmasına yönelik gerekli olan kritik yeterliklerin belirlenmesi ve adaylarının bu yeterliklere sahip olma olasılıklarının araştırılması amacıyla yapılan bu çalışma, bilişsel tanı modellerinden LCDM ile tasarlanmıştır. LCDM’nin ortalama ya da toplam gibi tek bir puana dayalı araştırmalara oranla daha güvenilir ve daha detaylı bilgi vermesi (Nichols ve diğ., 2012; Leighton ve Gierl, 2007), analiz sürecinde adayların yeterliklere sahip olma olasılıkları hesaplanırken maddelerin hiçbir yeterliğe sahip olmayanlar tarafından doğru cevaplanma olasılığının da dikkate alınması (Kuzu ve Arican, 2020), bu çalışmada LCDM'nin tercih edilmesinin bir nedeni olmuştur.

$\mathrm{Bu}$ nicel çalışmada, matematik ve fen bilgisi öğretmeni adaylarının integral konusundaki yeterliklere sahip olma olasılıkları ve bu olasılıkların öğrenim gördükleri bölüme göre incelemesinde tarama modeli kullanılmışken, integral konusundaki yeterliklere sahip olma olasılıklarının cinsiyete ve sınıf düzeyine göre incelenmesinde nedensel karşılaştırma modeli kullanılmıştır. Adayların yeterliklere sahip olma olasılıkları arasındaki ilişki ise korelasyon model ile araştırılmıştır. Matematik eğitimi üzerine ile ilgili araştırmalarda cinsiyet değişkenine göre incelemek temel amaç olmasa da önemli olduğu ifade edilmekte (Forgası, 2005) ve cinsiyetin matematik öğretim ve öğreniminde önemli bir faktör olduğunu ileri sürülmektedir (Armstrong, 1981; Ethington, 1992; Grossman ve Grossman, 1994; Lloyd, Walsh ve Yailagh, 2005). Tarama modeli, geçmişte ya da halen var olan bir durumu, görüşleri, ilgileri ve yeterlikleri olduğu şekliyle betimlemeyi amaçlayan bir araştırma modelidir (Karasar, 2014). Korelasyonel model ise iki veya daha fazla değişken arasındaki değişimin varlı̆ğ veya değişimin derecesi belirleyen bir modeldir (Fraenkel, Wallen ve Hyun, 2012).

\section{Çalışma Grubu}

Araştırmanın çalışma grubunu 2018-2029 eğitim-öğretim yılının güz döneminde öğrenim gören 67 (48’i kadın; 19’u erkek) matematik öğretmeni adayı ve bahar döneminde 
öğrenim gören 123 (109’u kadın; 14’ü erkek) fen bilgisi öğretmeni adayı oluşturmaktadır. 30 Mayıs 2018 tarihinde güncellenen lisans öğretim programı (YÖK, 2018) ile birlikte bu çalışmaya dâhil edilen 2. 3. ve 4. sınıf matematik ve fen bilgisi öğretmeni adayları eski lisans öğretim programına uygun olarak eğitim almaktadır. Eski öğretim programı (YÖK, 2007) çerçevesinde integral konusu 2. sınıf Analiz I dersinde yer alırken, yenilenen öğretim programı ile birlikte bu konu 1. sınıf Analiz II dersine alınmıştır. Fen bilgisi öğretmeni adaylarına yönelik hazırlanan her iki öğretim programında ise integral konusu 1. sınıf Genel Matematik II ders içeriğinde bulunmaktadır (YÖK, 2007, 2018). Bu bağlamda, araştırmaya dâhil edilen 1. sınıf matematik öğretmeni adaylarının lisans öğreniminde integral konusu ile henüz karşılaşmadığ1 (YÖK, 2018), ortaöğretim matematik dersi öğretim programı incelendiğinde ise bütün adayların 12. sınıfta integral konusu ile karşılaştığı bilinmektedir. (MEB, 2018).

$\mathrm{Bu}$ çalışmada, ilgili üniversitenin araştırmaya dâhil edilmesinde uygun örnekleme yöntemi kullanılmış olup, öğretmen adaylarının belirlenmesinde amaçsal örnekleme yöntemlerinden ölçüt örnekleme yöntemi kullanılmıştır. Amaçlı örnekleme yöntemi olasılığa dayalı olmayan bir örnekleme yöntemidir ve araştırmacı örneklemi kendi belirlediği ölçütlere göre belirler (Cohen, Manion ve Morrison, 2000). Ölçüt örnekleme ise önceden belirlenmiş bazı önemli kriterleri karşılayan vakaların seçilmesini içerir (Patton, 2002). Bu araştırmada, adayların eğitim-öğretim sürecinde integral konusunü görmüş olmaları ölçüt olarak alınmıştır. Araştırmanın çalışma grubuna ilişkin frekans dağ 1 ım Tablo 1'de sunulmuştur.

Tablo 1. Araştırmanın Çalışma Grubuna İlişkin Frekans Dağılımı

\begin{tabular}{lcccc}
\hline & \multicolumn{3}{c}{ Cinsiyet } & Toplam \\
\hline Bölüm & Kadın & Erkek & 67 \\
& Fen Bilgisi & 48 & 19 & 123 \\
Toplam & 109 & 14 & 190 \\
\hline
\end{tabular}

\section{Verilerin İşlenmesi ve Analizi}

Bu çalışmada, ilk olarak Kuzu (2017) tarafından Milli Eğitimi Bakanlığı tarafından hazırlanan 2017 Ortaöğretim Matematik Dersi Öğretim Programı kazanımları dikkate alınarak hazırlanan ve dört kazanım, dokuz alt kazanımdan oluşan çoktan seçmeli 25 maddelik "İntegral Kazanım İnceleme Testi (İKİT)” ele alınmıştır. İKİT'in KR-20 güvenirlik katsayıs1 .86; ortalama ayırt edicilik indeksi .53; ortalama güçlük indeksi ise .58 olarak hesaplanmıştır (Kuzu, 2017). Adayların integral konusuna yönelik kazanım performanslarını değerlendirmek amacıyla hazırlanan bu test incelenmiş ve bu çalışmada daha detaylı değerlendirmeye olanak tanıyan bilişsel tanı modellerinden LCDM ile yeniden tasarlanmıştır. Bu bağlamda dört kritik 
yeterliği (Y1: Belirli ve belirsiz integral kavramını açılar; Y2: Belirli ve belirsiz integral alma yöntemlerini bilir; Y3: Belirsiz integral hesabı yapar; Y4: Belirli integralleri kullanarak uygulamalar yapar) ölçen "İntegral Yeterlik İnceleme Testi (İYİT)” oluşturulmuştur (Bkz. Ek 1). Kavramsal bilgi için bireylerden ilgili kavramın tanımlanması ve açıklaması istenmektedir (Rittle-Johnson ve Schneider, 2015). İşlemsel bilginin ise ezberlenmiş işlem bilgisi olarak ifade edilmemesi gerektiği ve verilen bir problemin çözülmesi istenerek sonucun ya da işlemin doğruluğuna da bakılması gerektiği belirtilmektedir (Baroody, Feil ve Johnson, 2007, RittleJohnson ve Schneider, 2015). Bu bağlamda, daha çok tanımlamaya ve açıklamaya yönelik maddeleri içeren Y1 yeterliği ile; kavramın uygulanmasına yönelik yöntem ve kuralları bilmeye veya bu kuralları anlamlandırmadan ezberlemeye yönelik hazırlanan maddeleri içeren Y2 yeterliği kavramsal bilgi olarak belirlenmiştir. Tanımlama ve açıklamalara ihtiyaç duyulmayan, problemin çözüm sürecine ve sonucun doğruluğuna ezberlenmiş işlem bilgisi olarak bakılmayan veya algoritmaların, işlemlerin, yöntem ve kuralların uygulanmasına yönelik olan maddeleri içeren Y3 ve Y4 yeterlikleri ise işlemsel bilgi olarak dikkate alınmıştır.

Bu çalışmada bu dört kritik yeterliği ölçen ve yüksek madde-yeterlik ayırt edicilik indekslerine sahip olan bu testin her bir yeterliği sirasıyla $.99, .98, .99$, ve .95 güvenirlikle ölçtüğü belirlenmiştir. Bu süreçte öncelikle, istenilen kodların R 3.3.3 paket programı (R Core Team, 2017) ile kullanılması amacıyla Dr. Olga Kunina-Habenicht tarafından geliştirilen "Mplus Input Generator" programı yardımıyla Mplus 6.12 için bir LCDM kodu oluşturulmuştur. Sonrasında ise, Mplus 6.12 yardımıyla adayların integral konusundaki yeterliklere sahip olma olasılıkları hesaplanmış ve elde edilen değerler bölümleri, cinsiyetleri ve sınıf düzeyleri ile birlikte SPSS programına aktarılmıştır. Verilerin dağılımının normalliği betimsel (mod, medyan, aritmetik ortalama) ve grafiksel (histogram, box plot, Q-Q plot) yöntemler, çarpıklık ve basıklık katsayıları, Kolmogorov-Simirnov testi ile incelenmiş ve normallik şartının sağlanmadığı görülmüştür. $\mathrm{Bu}$ nedenle, adayların integral konusundaki yeterliklere sahip olma olasılıklarının bölüme ve cinsiyete göre farklılaşıp farklılaşmadığ Mann-Whitney U testi ile; sınıf düzeyine göre farklılaşıp farklılaşmadığı Kruskal Wallis-H testi ile; adayların bu dört kritik yeterliğe sahip olma olasılıklarının kendi aralarındaki ilişkisi ise Spearman Korelasyon testi araştırılmıştır. $\mathrm{Bu}$ çalışmada adayların integral konusundaki yeterliklere sahip olma olasılıkları için, $0 \leq$ olasılık $<20$ : Çok düşük, $20 \leq$ olasılık $<40$ : Düşük, $40 \leq$ olasılık < 60: Orta, $60 \leq$ olasılık < 80: Yüksek, $80 \leq$ olasılık $\leq 100$ : Çok Yüksek olarak ele alınmıştır. 


\section{Bulgular}

$\mathrm{Bu}$ bölümde LCDM modeline uygun olarak IYYIT'in hazırlanmasına ve bu test yardımıla adayların integral konusundaki yeterliklere sahip olma olasılıklarının araştırılmasına dair gerçekleşen süreç tablolar halinde ayrıntılı olarak sunulmuştur.

Bu çalışmada, öncelikle 2017 Ortaöğretim Matematik Dersi Öğretim Programı kazanımları ve alanyazında yer alan çalışmalar (Delice ve Sevimli, 2011; Kuzu, 2017; Rasslan ve Tall, 2002; Rösken ve Rolka, 2007; Tall ve Vinner, 1981; Vinner, 1991) incelenmiş ve integral konusunun anlaşılması için gerekli olan dört kritik yeterlik belirlenmiştir. $\mathrm{Bu}$ yeterliklerin uygunluğu için matematik eğitimi alanında uzman toplam beş öğretim üyesine bu testin hazırlanışı ve uygulanışı hakkında detaylı bilgiler verilmiştir. Sonrasında testteki her bir maddenin hangi yeterliği veya yeterlikleri ölçtüğünü belirlemek amaciyla uzmanlardan birbirinden bağımsız olarak test maddelerini ölçtükleri yeterlikler açısından ölçüyorsa "1”, ölçmüyorsa " 0 ” olacak şekilde kodlamaları istenmiştir. Rupp ve Templin'e (2008) göre ilgili yeterliğe ait maddelerin doğru kodlanması bilişsel tanı modellerindeki sınıflandırmanın doğruluğu açısından oldukça önemlidir. Bu sebeple, uzmanların herhangi bir maddenin ölçtüğü yeterliğe dair görüşleri alınmış ve Lawshe (1975) tekniği $\left.\left(N_{\text {ölçüyor }} /\left(N_{\text {toplam }} / 2\right)\right)-1\right)$ ile maddenin ilgili yeterliği ölçme oranı belirlenmiştir. Bir maddenin ilgili yeterliği ölçmesi için beş uzmana ilişkin olması gereken minimum değerin 99 olduğu belirtilmiştir (Veneziano ve Hooper, 1997). Elde edilen sonuca göre .99'dan küçük olan maddelerin ilgili yeterliği ölçmediği belirlenmiş ve sonuç olarak dört kritik yeterliği ölçen maddelerin dağılımını gösteren Q-matris (Tatsuoka, 1985) Tablo 2'deki gibi ortaya çıkmıştır.

Tablo 2. Kazanımların Ünite ve Sınıf Düzeyine Göre Dağ $11 ı m ı$

\begin{tabular}{llllllllllllllllllllllllllllll}
\hline Yeterlik & 1 & 2 & 3 & 4 & 5 & 6 & 7 & 8 & 9 & 10 & 11 & 12 & 13 & 14 & 15 & 16 & 17 & 18 & 19 & 20 & 21 & 22 & 23 & 24 & 25 & Toplam \\
\hline Y1 & 1 & 0 & 1 & 0 & 0 & 0 & 0 & 0 & 0 & 0 & 0 & 0 & 0 & 0 & 0 & 0 & 0 & 0 & 0 & 0 & 0 & 0 & 0 & 1 & 1 & 4 \\
Y2 & 0 & 0 & 0 & 0 & 0 & 1 & 1 & 1 & 1 & 1 & 1 & 1 & 0 & 0 & 1 & 1 & 1 & 1 & 1 & 0 & 0 & 1 & 0 & 1 & 0 & 14 & \\
Y3 & 0 & 1 & 0 & 1 & 1 & 0 & 1 & 1 & 1 & 1 & 1 & 0 & 1 & 1 & 0 & 1 & 0 & 0 & 1 & 1 & 0 & 0 & 0 & 0 & 0 & 13 & \\
Y4 & 0 & 0 & 0 & 0 & 0 & 0 & 0 & 0 & 0 & 0 & 0 & 0 & 1 & 0 & 0 & 0 & 0 & 0 & 1 & 1 & 1 & 0 & 1 & 0 & 0 & 5 & \\
\hline
\end{tabular}

Adayların Y1, Y2, Y3 ve Y4 yeterliğe sahip olma olasılıklarının araştırılması amacıyla öncelikle, istenilen kodların R 3.3.3 programı ile kullanılması amacıyla Mplus Input Generator programı yardımıyla Mplus 6.12 için bir LCDM kodu oluşturulmuştur. Sonrasında, Tablo 2'de yer alan Q-matris ve 


$$
\begin{aligned}
\ln \left(\frac{P\left(X_{e i}=1 \mid \alpha_{e}\right)}{P\left(X_{e i}=0 \mid \alpha_{e}\right)}\right)= & \lambda_{i, 0}+\lambda_{i, 1(1)}\left(\alpha_{e 1}\right)+\lambda_{i, 1(2)}\left(\alpha_{e 2}\right)+\lambda_{i, 1(3)}\left(\alpha_{e 3}\right)+\lambda_{i, 1(4)}\left(\alpha_{e 4}\right)+\lambda_{i, 2(1 * 2)}\left(\alpha_{e 1} \alpha_{e 2}\right) \\
& +\lambda_{i, 2(1 * 3)}\left(\alpha_{e 1} \alpha_{e 3}\right)+\lambda_{i, 2(1 * 4)}\left(\alpha_{e 1} \alpha_{e 4}\right)+\lambda_{i, 2(2 * 3)}\left(\alpha_{e 2} \alpha_{e 3}\right)+\lambda_{i, 2(2 * 4)}\left(\alpha_{e 2} \alpha_{e 4}\right) \\
& +\lambda_{i, 2(3 * 4)}\left(\alpha_{e 3} \alpha_{e 4}\right)+\lambda_{i, 3(1 * 2 * 3)}\left(\alpha_{e 1} \alpha_{e 2} \alpha_{e 3}\right)+\lambda_{i, 3(1 * 2 * 4)}\left(\alpha_{e 1} \alpha_{e 2} \alpha_{e 4}\right) \\
& +\lambda_{i, 3(1 * 3 * 4)}\left(\alpha_{e 1} \alpha_{e 3} \alpha_{e 4}\right)+\lambda_{i, 3(2 * 3 * 4)}\left(\alpha_{e 2} \alpha_{e 3} \alpha_{e 4}\right)+\lambda_{i, 4(1 * 2 * 3 * 4)}\left(\alpha_{e 1} \alpha_{e 2} \alpha_{e 3} \alpha_{e 4}\right)
\end{aligned}
$$

denklemi kullanılarak Mplus 6.12 programı ile istenilen olasılıklar hesaplanmıştır. Burada örneğin, $\lambda_{i, 0}$ parametresi LCDM'nin kesişim parametresidir ve hiçbir yeterliğe hâkim (mastered) olmayan adaylar için doğru yanıtın tahmin edilen log-olasılıklarını temsil etmektedir. $\lambda_{i, 1(1)}, \lambda_{i, 1(2)}, \lambda_{i, 1(3)}, \lambda_{i, 1(4)}$ parametreleri, temel etki parametreleridir ve örneğin $\lambda_{i, 1(2)}$ parametresi sadece Y2 yeterliğine hakim adaylar için doğru yanıtın tahmin edilen logolasılıklarını temsil etmektedir. Diğer parametreler ise etkileşim etki parametreleridir ve örneğin $\lambda_{i, 3(2 * 3 * 4)}$ parametresi için adayın Y2, Y3 ve Y4 yeterliklerine hâkim Y1 yeterliğine ise hâkim olmayan adaylar için doğru yanıtın tahmin edilen log-olasılıklarını temsil etmektedir. Devamında ise, en uyun LCDM modelinin belirlenmesi amaciyla MLR (Maximum Likelihood Robust-Maksimum Olasılık Gücü) ile log-olasılık değerleri kullanılarak (Satorra ve Bentler,

\begin{tabular}{|c|c|c|c|c|c|c|c|c|c|}
\hline Model & Tanımlamalar & AIC & BIC & SSA BIC & LL & NPR & Chd & $\mathrm{df}$ & $\mathrm{p}$ \\
\hline A & Tek yönlü yapısal model & 5301,23 & 5548,00 & 5307,26 & $-2574,61$ & 76 & - & - & - \\
\hline B & İki yönlü yapısal model & 5300,92 & 5586,66 & 5307,91 & $-2562,46$ & 88 & 22.35 & 1 & .00 \\
\hline $\mathrm{C}$ & Üç yönlü yapısal model & 5302,92 & 5591,91 & 5309,99 & $-2562,46$ & 89 & 0 & 1 & 1.00 \\
\hline $\mathrm{X}$ & En uygun model & 5280,83 & 5530,85 & 5286,94 & $-2562,46$ & 77 & - & - & - \\
\hline
\end{tabular}
2010) ve ki-kare fark testi yapılarak üç model birbiri ile karşılaştırılmış (Tablo 3).

Tablo 3. Tek Yönlü, İki Yönlü, Üç Yönlü Modeller ve Nihai Model için Model Modifikasyonları ve Uyum İndeksleri

AIC: Akaike ölçütü (Akaike’s information criteria); BIC: Bayes bilgi kriteri (Bayesian information criteria); SSA BIC: örneklem büyüklüğ̈̈ ayarlanmış Bayes bilgi kriteri (size adjusted Bayesian information criteria); LL: Log-olasılık (loglikelihood); NPR: Tahmini parametre sayısı (number of estimated parameters); Chd: Ki-kare fark1 (Chi-square difference); df: Serbestlik derecesi (Degrees of freedom)

Ki-kare farkının istatistiksel açıdan anlamlı olması $(\mathrm{p}<.05)$ temel, iki yönlü ve üç yönlü etkileşim etkileri (interaction effects) gibi daha serbest tahmin edilen parametrelere sahip daha büyük modelin daha az serbest tahmin edilen parametrelere sahip daha küçük modele göre verilere daha iyi uyacağını göstermektedir (Werner ve Schermelleh-Engel, 2010). Diğer taraftan ise p değerinin her iki modelde de anlamlı olması durumunda en tutucu modeli seçmek için bilgi kriterlerinin (AIC ve BIC) incelenmesi gerektiği vurgulanmıştır (Rupp ve diğ., 2010). Bu bağlamda, Tablo 3 incelendiğinde Model B'nin tek yönlü yapısal model olan Model A ve üç yönlü yapısal model olan Model C'ye oranla verilere daha iyi uyduğu görülmektedir $(\mathrm{p}<.05)$. Sonrasında, Model B'deki en uygun modeli belirlemek amacıyla adayların yeterliğe hâkim olup olmamasının belirlenmesine katkı sağlamayan iki yönlü etkileşim etkileri, en yüksek p 
değerinden başlanarak LCDM analizinden tek tek kaldırılmıştır. Her seferinde model tekrar çalıştırılarak analiz yapılmış, model uyum indeksleri kontrol edilmiş ve model uyumunun daha iyiye gidip gitmediği incelenmiştir. Model B'deki toplam 12 iki yönlü etkileşim etkilerinin içerisinden 5 etkileşim etkisinin kaldırılmasının model uyumunu iyileştirdiği gözlemlenmiş ve 7 tane iki yönlü etkileşim etkisinin anlamlı olduğu ortaya çıkmıştır. Ayrıca, Model B'de yer alan toplam 36 temel etkileşim etkileri içerisinden de 6'sının anlamlı olmadığ 1 sonucuna ulaşılmış ve bunlar ortadan kaldırılmıştır. Böylece, adayların yeterliklere sahip olma olasılıklarının hesaplanmasına anlamlı şekilde katkı sağlamayan tek ve çift yönlü etkileşim etkileri modelden çıkarılarak sınıflama problemleri giderilmiştir. Ayrıca, iki değişkenli model uyum bilgisi kullanılarak uyumsuz olan madde çiftleri belirlenmiş ve bunun yalnızca \%1.66'ya tekabül ettiği görülmüştür. Bu nedenle, bu çalışmada kullanılan test maddelerinin ve Q-matrisin ölçülmek istenilen yeterlikleri hesaplamadaki uygunluğu sağlanmıştır. Yapılan analiz sonucunda Model X adı verilen yeni model ile daha küçük uyum indekslerinin (AIC=5280.83; BIC: 5530.85, SSA BIC: 5286.94) indekslerinin ortaya çıtığı ve tahmini parametre sayısının 77 olduğu görülmüştür. Böylece bu yeni modelin kullanılmasına karar verilmiştir.

Tablo 4. Madde-Yeterlik Ayırt Edicilik İndeksleri

\begin{tabular}{|c|c|c|c|c|}
\hline Maddeler & Y1 & Y2 & Y3 & Y4 \\
\hline Madde 1 & .82 & & & \\
\hline Madde 2 & & & .69 & \\
\hline Madde 3 & .47 & & & \\
\hline Madde 4 & & & .57 & \\
\hline Madde 5 & & & .67 & \\
\hline Madde 6 & & .48 & & \\
\hline Madde 7 & & .64 & .54 & \\
\hline Madde 8 & & .67 & .71 & \\
\hline Madde 9 & & .82 & .76 & \\
\hline Madde 10 & & .91 & .93 & \\
\hline Madde 11 & & .69 & .71 & \\
\hline Madde 12 & & .78 & & \\
\hline Madde 13 & & & .61 & .76 \\
\hline Madde 14 & & & .81 & \\
\hline Madde 15 & & .57 & & \\
\hline Madde 16 & & .91 & .93 & \\
\hline Madde 17 & .88 & & & \\
\hline Madde 18 & & .49 & & \\
\hline Madde 19 & & .18 & .01 & .64 \\
\hline Madde 20 & & & .76 & 1.00 \\
\hline Madde 21 & & & & .84 \\
\hline Madde 22 & & .57 & & \\
\hline Madde 23 & & & & .92 \\
\hline Madde 24 & .77 & .45 & & \\
\hline Madde 25 & .47 & .41 & & \\
\hline
\end{tabular}

$\mathrm{Bu}$ çalışmada, bilişsel tanı modellerinde her bir maddenin istenilen yeterliğe sahip olan ve olmayan adayları ne düzeyde ayırt ettiğini belirlemek amacıyla madde-yeterlik ayırt edicilik 
indeksleri hesaplanmış ve elde edilen değerler Tablo 4'te ayrıntılı olarak sunulmuştur. Alanyazında madde-yeterlik ayırt edicilik indekslerine bağlı olarak test maddelerinin çıkarılması için bir kritik aralık belirtilmemiş, ancak .31'den aşağı değerlerin düşük olduğu vurgulanmıştır (de la Torre, 2008). Tablo 4 incelendiğinde ise, bu çalışmada 19. madde haricinde diğer bütün maddelerin madde-yeterlik ayırt edicilik indekslerinin yüksek olduğu görülmüştür. Ayrıca R 3.3.3 paket programı ile yapılan analizler sonucunda, bu testin her bir yeterliği sırasıyla $.99, .98, .99$, ve .95 güvenirlikle ölçtügü belirlenmiştir. Sonuç olarak, dört kritik yeterliği (Y1: Belirli ve belirsiz integral kavramını açıklar; Y2: Belirli ve belirsiz integral alma yöntemlerini bilir; Y3: Belirsiz integral hesab1 yapar; Y4: Belirli integralleri kullanarak uygulamalar yapar) ölçen ve yüksek madde-yeterlik ayırt edicilik indekslerine sahip olan “İntegral Yeterlik İnceleme Testi (IYYIT)” elde edilmiştir (Bkz. Ek 1).

Diğer taraftan, bu çalışmada, matematik ve fen bilgisi öğretmeni adaylarının integral konusundaki yeterliklere sahip olma olasılıklarının araştırılması amacıyla test maddelerine verilen yanıtlar 0 (yanlış cevap), 1 (doğru cevap) ve 9 (eksik cevap) şeklinde kodlanmıştır. Kodlanmış yanıtlar ve Tablo 2'de sunulan Q-matris, MPlus 6.12 programına aktarılmış ve LCDM kullanılarak her bir adayın ilgili yeterliğe bireysel olarak sahip olma olasılıkları hesaplanmıştır. Herhangi bir yeterlik ile ilişskili maddelerden alınan toplam ya da ortalama puanlar ilgili yeterliğe sahip olunup olunmadığını tam olarak açıklayamadığından bu çalışmada, teste verilen cevaplar doğrudan SPSS programına aktarılmamış ve her bir yeterlik için alınan toplam ve ortalama puanlar dikkate alınmamıştır. Örneğin, bazı adayların her bir yeterlik ile ilişkili maddelerden aldıkları toplam ve ortalama madde puanlar ile yeterliğe sahip olma olasılıkları Tablo 5'te ayrıntılı şekilde sunulmuştur.

Tablo 5. Bazı Adayların Her Bir Yeterlik ile İlişkili Olan Maddelerden Aldıkları Puanların Dağılımı

\begin{tabular}{|c|c|c|c|c|c|c|c|c|c|c|c|c|c|}
\hline \multirow{2}{*}{ No } & \multirow{2}{*}{ Yanitlar } & \multicolumn{3}{|c|}{ Y1 } & \multicolumn{3}{|c|}{$\mathrm{Y} 2$} & \multicolumn{3}{|c|}{ Y3 } & \multicolumn{3}{|c|}{ Y4 } \\
\hline & & $\mathrm{T}$ & $\mathrm{O}$ & $\mathrm{Y}$ & $\mathrm{T}$ & $\mathrm{O}$ & Y & $\mathrm{T}$ & $\mathrm{O}$ & $\mathrm{Y}$ & $\mathrm{T}$ & $\mathrm{O}$ & Y \\
\hline 25 & 0111011001111111000010011 & 3 & .750 & .594 & 8 & .571 & .594 & 8 & .615 & .406 & 2 & .400 & .365 \\
\hline 38 & 1110010000100010010000111 & 4 & 1.000 & .032 & 5 & .357 & .032 & 2 & .154 & .1000 & 1 & .200 & .1000 \\
\hline 73 & 0110011010111011111001101 & 2 & .500 & .090 & 11 & .786 & 987 & 7 & .538 & .910 & 3 & .600 & .013 \\
\hline 112 & 1011011010011110100100101 & 3 & .750 & .688 & 6 & .429 & .027 & 6 & .462 & .330 & 3 & .600 & .137 \\
\hline 164 & 1011111010111010100101111 & 4 & .1000 & .953 & 9 & .643 & .487 & 7 & .538 & .191 & 3 & .600 & .162 \\
\hline
\end{tabular}

$\mathrm{Bu}$ çalışmada, adayların Y1, Y2, Y3 ve Y4 yeterlikleri ile ilişkili maddelerden alınabileceği toplam maksimum puanların sırasıyla 4, 14, 13 ve 5 olduğu görülmektedir (Tablo 2). Tablo 5'de yer alan toplam ya da ortalama puanlar incelendiğinde, Aday 25'in Y1 yeterliğine sahip olma olasılığının Aday 38'e oranla daha düşük olduğu görülmektedir. LCDM 
analizi sonucunda ise Aday 25' in Y1 yeterliğine sahip olma olasılığının (\%59), Aday 38'in Y1 yeterliğine sahip olma olasılı̆̆ından (\%3) gerçekte daha yüksek olduğu belirlenmiştir. Ayrıca, Aday 73, Aday 112 ve Aday 164'ün toplam ve ortalama puanları incelendiğinde, adayların Y4 yeterliğine aynı düzeyde sahip olduğu görülmektedir. Oysaki LCDM analizi sonucunda, gerçekte Y4 yeterliğine sahip olma olasılıklarının farklı olduğu ve Aday 164'ün Y4 yeterliğine sahip olma olasılı̆̆ının (\%16) Aday 73 (\%13) ve Aday 112 (\%1)'ye oranla daha yüksek olduğu belirlenmiştir. Ortaya çıkan bu farklılıkların nedeni ise, LCDM analizinde bir adayın herhangi bir yeterlik ile ilişkili olan maddelere verilen yanıtların yanı sıra o yeterlik ile ilişkili olmayan maddelere verilen yanıtların da adayların yeterliklere sahip olma olasılıklarının hesaplanmasına etki etmesidir.

Diğer taraftan, bu çalışmada matematik ve fen bilgisi öğretmeni adaylarının integral konusundaki yeterliklere sahip olma olasılıkları incelenmiş, öğrenim gördükleri bölüme göre istatiksel açıdan farklılaşmanın olup olmadığı araştırılmış ve elde edilen bulgular Tablo 6'da sunulmuştur.

Tablo 6. İntegral Konusundaki Yeterliklere Sahip Olma Olasılıklarının Bölüme Göre MannWhitney U Testi Sonuçları

\begin{tabular}{clccccc}
\hline & Cinsiyet & Olasilık & Sira Ortalamas1 & Sira Toplam1 & U & $\mathrm{z}$ \\
\hline Y1 & Matematik & .992 & 150.63 & 10092.50 & $426.500^{*}$ & -10.349 \\
& Fen Bilgisi & .180 & 65.47 & 8052.50 & & \\
Y2 & Matematik & .886 & 148.69 & 9962.50 & $556.500^{*}$ & -9.899 \\
& Fen Bilgisi & .207 & 66.52 & 8182.50 & & \\
Y3 & Matematik & .104 & 125.71 & 2682.50 & $404.500^{*}$ & -10.449 \\
& Fen Bilgisi & .875 & 40.04 & 15462.50 & & \\
Y4 & Matematik & .063 & 125.87 & 2663.00 & $385.000^{*}$ & -10.387 \\
& Fen Bilgisi & .764 & 39.75 & 15482.00 & & \\
${ }^{*} \mathrm{p}<.05$ & & & & &
\end{tabular}

Tablo 6 incelendiğinde, matematik öğretmeni adaylarının Y1 (\%99) ve Y2 (\%88) yeterliklerine sahip olma olasılıklarının çok yüksek; Y3 (\%10) ve Y4 (\%6) yeterliklerine sahip olma olasıllklarının çok düşük olduğu görülmüştür. Fen bilgisi öğretmen adaylarının ise Y1 (\%18) yeterliğine sahip olma olasılıklarının çok düşük; Y2 (\%20) yeterliğine sahip olma olasılıklarının düşük, Y3 (\%87) yeterliğine sahip olma olasılıklarının çok yüksek ve Y4 (\%76) yeterliğine sahip olma olasılıklarının yüksek olduğu belirlenmiştir. Adayların integral konusundaki yeterliklere sahip olma olasılıklarının ise öğrenim gördükleri bölüme göre istatistiksel açıdan anlamlı olarak farklılaştığ 1 görülmüştür $(\mathrm{p}<.05)$. Bu farklılaşmanın $\mathrm{Y} 1$ ve Y2 yeterlikleri için matematik öğretmeni adaylarının lehine, Y3 ve Y4 yeterlikleri için ise fen bilgisi öğretmeni adaylarının lehine olduğu belirlenmiştir. Matematik öğretmeni adaylarının Y1 ve Y2 yeterliklerine sahip olma olasılı̆̆ diğer yeterliklere oranla daha yüksek iken, Y3 ve Y4 
yeterliklerine sahip olma olasılıklarının diğer yeterliklere oranla daha düşük olduğu görülmüştür. Fen bilgisi öğretmeni adaylarının ise matematik öğretmeni adaylarının aksine Y1 ve Y2 yeterliklerine sahip olma olasılıklarının diğer yeterliklere oranla daha yüksek olduğu, Y3 ve Y4 yeterliklerine sahip olma olasılıklarının ise daha düşük olduğu belirlenmiştir.

Diğer taraftan, adaylarının integral konusundaki yeterliklere sahip olma olasılıklarının cinsiyetlerine göre istatistiksel açıdan farklılaşıp farklılaşmadığı Mann-Whitney U testi ile araştırılmış ve elde edilen bulgular Tablo 7'de sunulmuştur.

Tablo 7. İntegral Konusundaki Yeterliklere Sahip Olma Olasılıklarının Cinsiyete Göre MannWhitney U Testi Sonuçları

\begin{tabular}{|c|c|c|c|c|c|c|c|}
\hline Bölüm & Yeterlikler & Cinsiyet & Olasılik & Sira Ortalaması & Sira Toplamı & $\mathrm{U}$ & $\mathrm{Z}$ \\
\hline \multirow[t]{8}{*}{ Matematik } & \multirow[t]{2}{*}{$\mathrm{Y} 1$} & Kadın & .936 & 35.02 & 1681.00 & \multirow[t]{2}{*}{407.000} & \multirow[t]{2}{*}{-.715} \\
\hline & & Erkek & .886 & 31.42 & 597.00 & & \\
\hline & \multirow[t]{2}{*}{ Y2 } & Kadın & .905 & 33.97 & 1630.50 & \multirow[t]{2}{*}{454.500} & \multirow[t]{2}{*}{-.021} \\
\hline & & Erkek & 837 & 34.08 & 647.50 & & \\
\hline & \multirow[t]{2}{*}{ Y3 } & Kadın & .100 & 33.26 & 1596.50 & \multirow[t]{2}{*}{420.500} & \multirow[t]{2}{*}{-.518} \\
\hline & & Erkek & .113 & 35.87 & 681.50 & & \\
\hline & \multirow[t]{2}{*}{ Y4 } & Kadın & .050 & 33.48 & 1607.00 & \multirow[t]{2}{*}{431.000} & \multirow[t]{2}{*}{-.369} \\
\hline & & Erkek & .097 & 35.32 & 671.00 & & \\
\hline \multirow[t]{8}{*}{ Fen Bilgisi } & \multirow[t]{2}{*}{ Y1 } & Kadın & .194 & 65.18 & 7105.00 & \multirow[t]{2}{*}{$416.000^{*}$} & \multirow[t]{2}{*}{-2.888} \\
\hline & & Erkek & .071 & 37.21 & 521.00 & & \\
\hline & \multirow[t]{2}{*}{ Y2 } & Kadın & .218 & 64.44 & 7023.50 & \multirow[t]{2}{*}{$497.500^{*}$} & \multirow[t]{2}{*}{-2.155} \\
\hline & & Erkek & .122 & 43.04 & 602.50 & & \\
\hline & \multirow[t]{2}{*}{ Y3 } & Kadın & .868 & 59.99 & 6538.50 & \multirow[t]{2}{*}{543.500} & \multirow[t]{2}{*}{-1.853} \\
\hline & & Erkek & .928 & 77.68 & 1087.50 & & \\
\hline & \multirow[t]{2}{*}{ Y4 } & Kadın & .763 & 60.87 & 6634.50 & \multirow[t]{2}{*}{639.500} & \multirow[t]{2}{*}{-.998} \\
\hline & & Erkek & .775 & 70.82 & 991.50 & & \\
\hline
\end{tabular}

Tablo 7 incelendiğinde, kadın matematik öğretmeni adaylarının integral konusundaki Y1, Y2, Y3 ve Y4 yeterliklerine sahip olma olasılıklarının sirasıly \%93, \%90, \%10 ve \%5 olduğu görülürken, erkek adayların bu yeterliklere sahip olma olasılıklarının \%88, \%83, \%11 ve \%9 olduğu belirlenmiştir. Kadın fen bilgisi öğretmen adaylarının integral konusundaki yeterliklere sahip olma olasılıkları ise sirasıly $\% 19, \% 21, \% 86$ ve $\% 76$ olarak bulunurken, erkek adayların bu yeterliklere sahip olma olasılıklarının \%7, \%12, \%92 ve \%77 olduğu görülmüştür. Yapılan analizler sonucunda, matematik öğretmeni adaylarının integral konusundaki yeterliklere sahip olma olasılıklarının cinsiyete göre istatistiksel açıdan anlamlı olarak farklılaşmadığı belirlenmiştir ( $\mathrm{p}>.05$ ). Buna göre, integral kavramını açıklama ve integral alma yöntemlerini bilme yeterliklerine hem kadın hem de erkek matematik öğretmeni adaylarının daha yüksek olasılıkla sahip olduğu, Y3 ve Y4 yeterliklerine sahip olma olasılıklarının ise daha düşük olduğu görülmüştür. Böylece hem kadın hem de erkek matematik öğretmeni adaylarının integral konusuna yönelik kavram ve yöntem bilgisinin işlem bilgisine oranla daha yüksek olduğu ortaya çıkmıştır. Diğer taraftan, fen bilgisi öğretmeni adayları için 
Y1 ve Y2 yeterliklerine sahip olma olasılıklarında kadınların lehine istatistiksel açıdan anlamlı bir farklılık görülmüşken $(\mathrm{p}<.05)$; Y3 ve Y4 yeterliklerine sahip olma olasılıklarında ise cinsiyete göre anlamlı bir farklılaşmanın olmadığı görülmüştür. Bu durumda, kadın fen bilgisi öğretmeni adaylarının integral kavramını açıklama ve integral alma yöntemlerini bilme yeterliklerine erkek fen bilgisi öğretmeni adaylarına oranla daha yüksek olasılıkla sahip olduğu belirlenmiştir. Hem kadın hem de erkek fen bilgisi öğretmeni adaylarının integral konusuna yönelik işlem bilgisinin kavram ve yöntem bilgisine oranla daha yüksek olduğu ortaya çıksa da kadın fen bilgisi öğretmen adaylarının erkek adaylara oranla kavramsal bilgiye daha çok yoğunlaştığ1 ve yöntem bilgisinin daha yüksek olduğu ortaya çıkmıştır.

Diğer taraftan, adaylarının integral konusundaki yeterliklere sahip olma olasılıklarının sınıf düzeyine göre istatistiksel açıdan farklılaşıp farklılaşmadığı Kruskal-Wallis H testi ile; farklılaşmanın hangi gruplar arasında olduğunu belirlemek için ise Mann-Whitney U testi ile araştırılmış ve elde edilen bulgular Tablo 8'de sunulmuştur.

Tablo 8. İntegral Konusundaki Yeterliklere Sahip Olma Olasılıklarının Sınıf Düzeyine Göre Kruskal-Wallis H Testi Sonuçları

\begin{tabular}{|c|c|c|c|c|c|c|c|}
\hline & & Sinif & Olasıl1k & Sira Ortalaması & Sd & $\chi^{2}$ & Fark \\
\hline \multirow[t]{16}{*}{ Matematik } & Y1 & 1 & .605 & 18.90 & 3 & $9.855^{*}$ & $1-2$ \\
\hline & & 2 & .972 & 37.94 & & & $2-4$ \\
\hline & & 3 & .932 & 31.46 & & & \\
\hline & & 4 & .644 & 11.83 & & & \\
\hline & Y2 & 1 & .606 & 16.40 & 3 & $11.969^{*}$ & $1-2$ \\
\hline & & 2 & .936 & 38.46 & & & $2-4$ \\
\hline & & 3 & .856 & 31.36 & & & \\
\hline & & 4 & .333 & 8.83 & & & \\
\hline & Y3 & 1 & .395 & 49.10 & 3 & $9.849^{*}$ & $1-2$ \\
\hline & & 2 & .051 & 29.88 & & & $2-4$ \\
\hline & & 3 & .115 & 37.32 & & & \\
\hline & & 4 & .355 & 55.17 & & & \\
\hline & Y4 & 1 & .084 & 47.90 & 3 & $9.241^{*}$ & $2-4$ \\
\hline & & 2 & .043 & 29.86 & & & \\
\hline & & 3 & .060 & 38.18 & & & \\
\hline & & 4 & .340 & 53.50 & & & \\
\hline \multirow[t]{16}{*}{ Fen Bilgisi } & Y1 & 1 & .208 & 66.02 & 3 & $8.925^{*}$ & $1-3$ \\
\hline & & 2 & .039 & 46.21 & & & \\
\hline & & 3 & .000 & 34.14 & & & \\
\hline & & 4 & .099 & 47.07 & & & \\
\hline & Y2 & 1 & .226 & 65.14 & 3 & 4.928 & - \\
\hline & & 2 & .141 & 46.86 & & & \\
\hline & & 3 & .105 & 43.64 & & & \\
\hline & & 4 & .101 & 49.71 & & & \\
\hline & Y3 & 1 & .859 & 58.26 & 3 & $7.999^{*}$ & $1-3$ \\
\hline & & 2 & .884 & 72.00 & & & \\
\hline & & 3 & .999 & 85.14 & & & \\
\hline & & 4 & .964 & 83.29 & & & \\
\hline & Y4 & 1 & .749 & 59.85 & 3 & 2.633 & - \\
\hline & & 2 & .865 & 78.93 & & & \\
\hline & & 3 & .829 & 70.93 & & & \\
\hline & & 4 & .810 & 67.50 & & & \\
\hline
\end{tabular}


Tablo 8 incelendiğinde, matematik öğretmeni adayları için Y1 ve Y2 yeterliklerine sahip olma olasılıklarının en yüksek 2. ve 3. sınıf düzeyinde; Y3 yeterliğine sahip olma olasılığının 1. ve 4. sınıf düzeyinde; Y4 yeterliğine sahip olma olasılığının ise 4. sınıf düzeyinde ortaya çıktığı görülmektedir. Fen bilgisi öğretmeni adayları için ise Y1 ve Y2 yeterliklerine sahip olma olasılıklarının en yüksek 1. sınıf düzeyinde; Y3 yeterliğine sahip olma olasılığının bütün sınıf düzeylerinde; Y4 yeterliğine sahip olma olasılığının ise 2. 3 ve 4. sınıf düzeyinde ortaya çıktığı belirlenmiştir. Yapılan analizler sonucunda matematik öğretmeni adayları için bütün yeterliklerde, fen bilgisi öğretmeni adayları için ise Y1 ve Y3 yeterliklerinde istatistiksel açıdan anlamlı bir farklılaşma görülmüştür $(\mathrm{p}<.05)$. Matematik öğretmeni adaylarının Y1 ve Y2 yeterliklerine sahip olma olasılıklarına bakılırsa, 2. sınıf düzeyinde öğrenim gören adaylar ile 1. ve 4. sınıf düzeyinde öğrenim gören adaylar arasında 2. sınıfların lehine anlamlı bir farklılık vardır. Fen bilgisi öğretmeni adayları için Y1 yeterliğine sahip olma olasılıklarına bak1lırsa, 1. sınıfta öğrenim gören adaylar lehine, Y3 yeterliğine sahip olma olasılıklarına bakılırsa 3. sınıfta öğrenim gören adaylar lehine anlamlı bir farklılık vardır.

Diğer taraftan, adayların integral konusundaki yeterliklere sahip olma olasılıkları arasındaki ilişki ise Spearman Korelasyon testi araştırılmış ve elde edilen bulgular Tablo 9'da sunulmuştur.

Tablo 9. İntegral Konusundaki Yeterliklere Sahip Olma Olasılıkları Arasındaki İlişkiye Yönelik Spearman Korelasyon Testi Sonuçları

\begin{tabular}{|c|c|c|c|c|c|}
\hline \multirow[b]{2}{*}{ r } & & \multicolumn{4}{|c|}{ Yeterlikler } \\
\hline & & Y1 & $\mathrm{Y} 2$ & Y3 & Y4 \\
\hline \multirow[t]{3}{*}{ Matematik } & Y1 & & $.826^{*}$ &.$-996 *$ & .-972* \\
\hline & Y2 & & &.$-834^{*}$ &.$-808^{*}$ \\
\hline & Y3 & & & & $.980 *$ \\
\hline \multirow[t]{3}{*}{ Fen Bilgisi } & $\mathrm{Y} 1$ & & $.861^{*}$ &.$-652 *$ &.$-333 *$ \\
\hline & Y2 & & &.$-530 *$ &.$-444^{*}$ \\
\hline & Y3 & & & & $.362 *$ \\
\hline
\end{tabular}

Tablo 9 incelendiğinde, matematik ve fen bilgisi öğretmeni adaylarının integral konusundaki yeterliklere sahip olma olasılıkları için bütün yeterlikler arasında istatistiksel açıdan anlamlı bir ilişki görülmektedir $(\mathrm{p}<.05)$. Elde edilen korelasyon katsayısı $(\mathrm{r}), \mathrm{r}<.20$ ise çok zayıf; . $20<\mathrm{r}<.40$ ise zayıf; . $40<\mathrm{r}<.60$ ise orta; . $60<\mathrm{r}<.80$ ise yüksek; . $80<\mathrm{r}$ ise çok yüksek düzeyde ilişkinin olduğunu göstermektedir (Evans, 1996). Buna göre, matematik öğretmeni adaylarının Y1-Y2 ve Y3-Y4 yeterliklerine sahip olma olasılıklar1 arasında pozitif yönde çok yükssek düzeyde anlamlı bir ilişki bulunmuştur. Ayrıca, Y1-Y3, Y1Y4, Y2-Y3 ve Y2-Y4 yeterliklerine sahip olma olasılıkları arasında ise negatif yönde ancak yine çok yüksek düzeyde anlamlı bir ilişkinin olduğu görülmüştür. Diğer taraftan, fen bilgisi 
öğretmeni adaylarının Y1-Y2 yeterliklerine sahip olasılıkları arasında pozitif yönde çok yüksek düzeyde; Y3-Y4 yeterliklerine sahip olma olasılıkları arasında ise yine pozitif yönde ancak zayıf düzeyde anlamlı bir ilişki bulunmuştur. Ayrıca, Y1-Y3 yeterliklerine sahip olma olasılıkları arasında negatif yönde yüksek düzeyde, Y1-Y4 yeterliklerine sahip olma olasılıkları arasında yine negatif yönde ancak zayıf düzeyde, Y2-Y3 ve Y2-Y4 yeterliklerine sahip olma olasılıkları arasında ise negatif yönde yüksek düzeyde anlamlı bir ilişki olduğu görülmüştür.

\section{Sonuç, Tartışma ve Öneriler}

$\mathrm{Bu}$ çalışmada, matematik ve fen bilgisi öğretmeni adaylarının integral konusundaki yeterliklere sahip olma olasılıklarını araştırmak, güçlü ve zayıf yönleri hakkında tanısal değerlendirmeler yapmak amacıyla integral yeterlik inceleme testi hazırlanmış ve bilişsel tanı modellerinden LCDM kullanarak analiz edilmiştir. MPlus yardımıyla yapılan analiz sonucunda matematik ve fen bilgisi öğretmeni adaylarının integral konusunda ölçülmek istenilen yeterliğe hangi olasılıkla sahip oldukları hesaplanmıştır. Buna göre, matematik öğretmeni adaylarının işlemsel bilgiye oranla çok yüksek olasılıkla integral kavramını açıklayabildiği (\%99) ve integral alma yöntemlerini bildiği (\%88) görülmüş; kavramsal bilgi düzeylerinin işlemsel bilgi düzeylerine oranla daha yüksek olduğu belirlenmiştir. Buna göre, matematik öğretmeni adaylarının işlem bilgilerinin kavram ve yöntem bilgilerine oranla daha düşük olduğu görülmüştür. Adayların kavram bilgisi yeterliklerine yüksek oranda sahip olmaları, daha sonra öğreneceği ilişkili konuların öğreniminde temel oluşturacak ve öğrenme sürecine olumlu katkı sağlayacaktır (Kuzu, 2017). Adayların kavramsal bilgi yeterliklerinin yüksek olması ise problem çözme sürecinde oldukça önemli bir yer tutmaktadır (Soylu ve Soylu, 2006). Kavram öğretiminde ve problem çözme sürecinde birden çok temsil kullanılması, kavramsal anlama düzeylerinin ve bilişsel süreç becerilerinin gelişmesine katkı sağlayacağından (Kuzu, 2020a), soyut bir yapıya sahip olan integralin anlamlandırılması sürecinde farklı temsil türlerinden yararlanılarak çeşitli etkinlikler planlanabilir.

$\mathrm{Bu}$ çalışmada elde edilen sonucun aksine geçmiş yıllarda integral üzerine yapılan çalışmalar incelendiğinde ise matematik öğretmeni adaylarının integral konusuna yönelik kavram bilgilerinin işlem bilgilerine oranla daha düşük olduğu belirtilmiştir (Delice ve Sevimli, 2010). Ortaya çıkan bu farklılığın nedeni, integral öğretim sürecindeki yöntemlerin değişkenlik göstermesinden kaynaklı olabilir. Normal öğretim sürecinde ders kitabındaki ve öğretim programındaki sıranın dikkate alındığı (Sevimli, 2009) ve belirsiz integral ile giriş yapıldığ (Akkoç ve Kurt, 2008) belirtilmiştir. Belirsiz integral ile ders sürecine başlanmasının ise 
kavramsal öğrenmeyi güçleştireceği yapılan çalışmalar ile vurgulanmıştır (Orton, 1983; Rasslan ve Tall, 2002). Her ne kadar bilişsel yaklaşımlar, son öğrenilen kavramların daha çok hatırlandığını ve önceki bilgilerin daha çabuk unutulduğunu belirtse de (Brookfield, 2005), integral öğretiminde konuya ilk girişin kavramın anlamlandırılması sürecinde oldukça etkili olduğunu göstermektedir (Delice ve Sevimli, 2011). Bu çalışmada ise matematik öğretmeni adayları için normal öğretim sürecinin aksine belirli integral ile ders sürecine başlandığı ve adaylarda kavramsal olarak bir integral imgesinin oluştuğu dersi veren öğretim üyesi ile yapılan görüşme sonucunda ortaya çıkmıştır:

“...Bir aralığın parçalanışını, Riemann toplamını ve sonlu toplamların limitini dikkate alarak belirli integral kavramı ile derse başlarım. Devamında ise belirsiz integral kavramına geçerim ve cebirsel hesaplamalara yer veririm...”

Fen bilgisi öğretmen adaylarının ise yüksek olasılıkla belirsiz integral hesabı yapabildiğ $i$ (.76), çok yüksek olasılıkla da belirli integralleri kullanarak uygulamalar yapabildiği (\%87) görülmüş; işlemsel bilgi düzeylerinin kavramsal bilgi düzeylerinden daha yüksek olduğu ortaya çıkmıştır. Özden ve Yenice (2016) tarafından yapılan çalışmada da fen bilgisi öğretmen adaylarının teori ve kanunları net olarak ifade edemedikleri ve kavramları açıklamada zorlandıkları belirtilmiştir. Öğretim sürecinde, kavramsal öğrenmenin önemli olduğu bilinse de daha çok hesap temelli yaklaşımların benimsenmesi ve işlemsel öğrenmeye ağırlık verilmesi (Sevimli, 2009) ortaya çıkan bu sonucun bir nedeni olabilir. Oysaki kavram bilgisine yönelik yeterliklerinin yüksek olması, beraberinde integral konusuna ait farklı tanımları ve bu tanımlara ait farklı bağlamları birbiri ile ilişkilendirebilmelerine zemin hazırlamaktadır (Delice ve Sevimli, 2010). Bu nedenle, fen bilgisi öğretmeni adaylarının işlemsel bilgi düzeyindeki integral sorularında başarı gösterseler dahi bu bilgileri yorumlamada ve farklı bir bağlamda kullanabilmeleri için kavram bilgisi ile işlem bilgisi arasında bir bağ kurulmasının fayda sağlayacağ1 düşünülmektedir. Kavramsal ve işlemsel bilgi düzeyinde yetkin öğrencilerin yetiştirilmesinin öğretim yöntemlerinin tercihi ile yakından ilişkili olduğu düşünüldüğünde ise integral konusunun anlaşılmasına yönelik kavram ve yöntem bilgisini içeren yeterlikler ile işlem bilgisini içeren yeterliklerin gelişimini sağlayacak öğretim yöntemlerinin kullanılmasında yarar vardır.

Diğer taraftan, bu çalışmada integral konusundaki yeterliklere sahip olma olasılıklarının cinsiyete göre anlamlı olarak farklılaşmadığı görülse de kadın matematik öğretmeni adaylarının kavramsal bilgi düzeylerinin; erkek matematik öğretmeni adaylarının ise işlemsel bilgi düzeylerinin daha yüksek olduğu görülmüştür. Fen bilgisi öğretmeni adayları için ise Y1 ve Y2 
yeterliklerine sahip olma olasılıklarında kadınların lehine anlamlı bir farklılık bulunmuş ve kadın fen bilgisi öğretmeni adaylarının erkek fen bilgisi öğretmeni adaylarına oranla kavramsal bilgiye daha çok yoğunlaştı̆̆ı; kavram ve yöntem bilgilerinin daha yüksek olduğu ortaya çıkmıştır. Erkek fen bilgisi öğretmeni adaylarının kadın fen bilgisi öğretmeni adaylarına oranla ise işlemsel bilgi düzeylerinin daha yüksük olduğu belirlenmiştir. Kavramsal bilginin ilişkisel öğrenme, işlemsel bilginin ise kurallı anlama olarak ifade edildiği (Skemp, 1976) göz önüne alındığında kadın adayların ilişkisel, erkek adayların ise kurallı anlamaya yönelik integral yeterliklerinin yüksek olduğu söylenebilir.

$\mathrm{Bu}$ çalışmada, matematik öğretmeni adayları için bütün yeterliklerde, fen bilgisi öğretmeni adayları için ise Y1 ve Y3 yeterliklerinde adayların öğrenim gördükleri sınıf düzeyine göre istatistiksel açıdan anlamlı bir farklılaşma görülmüştür. Matematik öğretmeni adaylarının Y1 ve Y2 yeterliklerine sahip olma olasılıklarına bakılırsa, 2. sınıfta öğrenim gören adaylar ile 1. ve 4. sınıfta öğrenim gören adaylar arasında 2. sınıfların lehine anlamlı bir farklılık vardır. Kavram ve yöntem bilgilerinin ön plana çıktığ1 Y1 ve Y2 yeterliklerinin 2. sınıfta öğrenim gören matematik öğretmeni adaylarında yüksek olmasının bir nedeni olarak integral konusunun 2. sınıf matematik öğretim programında yer alan Analiz I dersi kapsamında verilmiş olması gösterilebilir (YÖK, 2007, 2018). Y3 ve Y4 gibi işlemsel bilgi düzeyindeki yeterliklere sahip olma olasılıklarının 4. sınıfta öğrenim gören matematik öğretmeni adaylarda yüksek olmasının nedeni ise bu yıl girecekleri kamu personeli seçme sınavında öğretmenlik alan bilgisi testinde integral uygulamalarına yönelik soruların çıkması söylenebilir (ÖSYM, 2019). Fen bilgisi öğretmeni adaylarının için Y1 yeterliğine sahip olma olasılıklarına bakılırsa, 1. sınıfta öğrenim gören adaylar lehine, Y3 yeterliğine sahip olma olasılıklarına bakılırsa 3. sınıfta öğrenim gören adaylar lehine anlamlı bir farklılık vardır. Kavramsal bilginin ön plana çıktığı Y1 yeterliğine ait ders içeriklerinin 1. sınıf fen bilgisi öğretim programında yer alan Genel Matematik II dersi kapsamında verilmiş olması gösterilebilir (YÖK, 2007, 2018).

Diğer taraftan, matematik ve fen bilgisi öğretmeni adaylarının integral konusundaki yeterliklere sahip olma olasılıkları için bütün yeterlikler arasında istatistiksel açıdan anlamlı bir ilişki görülmüş̧ür. Bu ilişkinin yönü incelendiğinde, kavramsal bilgi düzeyindeki yeterliklerin ve işlemsel bilgi düzeyindeki yeterliklerin kendi aralarında pozitif yönde bir ilişki içeresinde oldukları görülmüştür. Ancak, adayların integral kavramını açıklama ve integral alma yöntemlerini bilme gibi kavramsal bilgi düzeyindeki yeterliklere sahip olma olasılıkları ile belirsiz integral hesabı yapma ve belirli integralleri kullanarak uygulamalar yapma gibi işlem bilgisine sahip olma olasılıkları arasındaki ilişkinin ise negatif yönde olduğu dikkatleri 
çekmiştir. Bu durumda, integrale yönelik kavram bilgisi yüksek olan bir adayın işlem bilgisini düşük, işlem bilgisinin yüksek olan bir adayın ise kavram bilgisinin düşük olduğu ortaya çıkmıştır. Oysaki matematiksel bilginin içselleştirilmesi ve ilişkilendirilmesi ile oluşan kavramsal bilginin, işlemsel bilgiye anlam kazandırdığı (Hiebert ve Lefevre, 1986), matematik öğretiminde her iki bilgi türüne de ihtiyaç duyulduğu ve birinin diğerinden daha önemli olmadığ 1 belirtilmiştir (Ersoy, 2002).

İntegral konusuna yönelik kavramsal ve işlemsel bilgi düzeyindeki yeterliklere ne oranda sahip olunduğunu bilmek integral konusunun anlaşılmasına, güçlü ve zayıf yönlerinin belirlenmesine dair tanısal değerlendirmelere imkân sunmaktadır. Konunun tam olarak içselleştirilmesi ise bu bilgi düzeyindeki yeterliklere birlikte sahip olma oranıyla yakından ilişkilidir. Genelleme ve soyutlama becerisinin ortaya çıkması amacıyla kavramsal öğrenmeye yönelik bir öğretim sürecinin gerçekleşmesi (Bekdemir, 2012), kavramsal ve işlemsel bilgi arasında bir bağ ve denge kurulmasına imkân tanıyabilir. Ayrıca, öğretim programının amaç ve hedefleri dikkate alınarak öğrenciyi sürece dâhil eden ve aktif katılımını sağlayan süreç temelli öğretim yaklaşımlarının kullanılması ve problemlerin günlük hayat ile ilişkilendirilmesi daha anlamlı öğrenmenin oluşmasına ve öğrenci performanslarının artmasına zemin hazırlayacaktır (Kuzu, Çil ve Şimşek, 2019). Böylece, soyut olan integral konusunun somutlaştırması ile işlemsel bilgiye yönelik yeterliklerin de yükselmesine ortam sağlanabilir. Ayrıca, öğretim sürecinde integralin gerçek hayat uygulamaları ile uzamsal görselleştirmeye ve dijital modellemeye imkân sunan çeşitli görsel ve teknolojik süreçlere yer verilerek ders içerikleri daha zengin hale getirilebilir.

\section{Makalenin Bilimdeki Konumu}

Matematik ve Fen Bilimleri Eğitimi Bölümü, Matematik Eğitimi Ana Bilim Dalı

\section{Makalenin Bilimdeki Özgünlüğü}

Analiz biliminin temel kavramları arasında yer alan integral kavramının öğrenilmesi, öğretilmesi ve anlamlandırılması en güç kavramlar arasında olduğu bilinmektedir. Anlamlandırmanın tam olarak sağlanabilmesi için ise anlamanın doğasında yer alan kavramsal ve işlemsel bilginin birbiri ile dengeli bir bağ içerisinde olması gerekmektedir. Bu sebeple, integral konusuna yönelik kavramsal ve işlemsel bilgi düzeyindeki yeterliklere hangi oranda sahip olunduğunu bilmek, bu yeterlikler hakkında eğitimcilere bilişsel geri bildirimler sağlaması ve adayların bilişsel olarak güçlü ve zayıf yönleriyle ilgili daha detaylı bilgiler 
sunması açısından önemli görülmektedir. Bu bağlamda, matematik ve fen bilgisi öğretmeni adaylarının integral konusuna yönelik kavramsal ve işlemsel bilgi düzeyindeki yeterliklere sahip olma olasılıkları daha güvenilir ve daha detaylı değerlendirmeye olanak tanıyan bilişsel tanı modellerinden log-lineer diagnostic model kullanılarak hesaplanmıştır.

\section{Kaynaklar}

Arican, M. (2019). A diagnostic assessment to middle school students’ proportional reasoning. Turkish Journal of Education, 8(4), 237-257.

Arican, M., \& Kuzu, O. (2020). Diagnosing preservice teachers’ understanding of statistics and probability: Developing a test for cognitive assessment. International Journal of Science and Mathematics Education, 18(4), 771-790.

Akkoç, H. ve Kurt, S. (2008). İntegral kavramına ilişkin öğrenme zorlukları ve integral öğretimi. M. F. Özmantar, E. Bingölbali \& H. Akkoç (Eds.), Matematiksel Kavram Yanılgıları ve Çözüm Önerileri, Ankara: Pegem Akademi Yayıncılık.

Armstrong, J. M. (1981). Achievement and participation of women in mathematics: Results of two national surveys. Journal for Research in Mathematics Education, 12(5), 356-372.

Aydın, E. ve Önder, O. (2010). Sınava hazırlık biçiminin farklı sınav türlerinde ölçülen matematik sınav başarı düzeylerine etkisi. Marmara Üniversitesi Atatürk Ĕ̌gitim Fakültesi Eğitim Bilimleri Dergisi, 31(31), 5-24.

Baki, A. (1997). Çağdaş gelişmelerin 1şığında matematik öğretmenliği eğitim programları. Ë̆itim ve Bilim, 21(103), 46-54.

Baroody, A. J. (2003). The development of adaptive expertise and flexibility: The integration of conceptual and procedural knowledge. In A. J. Baroody \& A. Dowker (Eds.), The development of arithmetic concepts and skills: Constructive adaptive expertise (pp. 134). Mahwah, NJ: Erlbaum.

Baroody, A. J., Feil, Y., \& Johnson, A. R. (2007). An alternative reconceptualization of procedural and conceptual knowledge. Journal for research in mathematics education, 38(2), 115-131.

Bekdemir, M. (2012). Öğretmen adaylarının çember ve daire konularında kavram ve işlem bilgilerinin değerlendirilmesi. Hacettepe Üniversitesi Eğitim Fakültesi Dergisi, 43, 8395.

Bender, N. (2014). Changing definitions of learning disabilities. Learning Disabilities, Characteristics, Identification, and Teaching Strategies. Allyn \& Bacon: Pearson Inc. 
Bradshaw, L., Izsak, A., Templin, J., \& Jacobson, E. (2014). Diagnosing teachers' understandings of rational numbers: Building a multidimensional test within the diagnostic classification framework. Educational Measurement: Issues and Practice, 33(1), 2-14.

Brookfield, S. (2005). The power of critical theory for adult learning and teaching. Maidenhead: Open University Press.

Byrnes, J. P., \& Wasik, B. A. (1991). Role of conceptual knowledge in mathematical procedural learning. Developmental psychology, 27(5), 777.

Camacho, M., Depool, R., \& Santos-Trigo, M. (2004). Promoting students' comprehension of definite İntegral and area concepts through the use of derive software. Proceedings of the 26th Psychology of Mathematics Education (pp. 447-454). Norwich, United Kingdom.

Camacho-Machin, M., Depool-Rivero, R., \& Santos-Trigo, M. (2010). Students’ use of derive software in comprehending and making sense of definite integral and area concepts. CBMS Issues in Mathematics Education, 16, 29-61.

Canobi, K. H. (2009). Concept-procedure interactions in children's addition and subtraction. Journal of experimental child psychology, 102(2), 131-149.

Carpenter, T. P. (1986). Conceptual knowledge as a foundation for procedural knowledge: Implications from research on the initial learning of arithmetic. In J. Hiebert (Ed.), Conceptual procedural knowledge: The case of mathematics (pp. 113-132). Hillsdale, NJ: Erlbaum.

Chappell, K. K., \& Killpatrick, K. (2003). Effects of concept-based instruction on students' conceptual understanding and procedural knowledge of calculus. Problems, Resources, and Issues in Mathematics Undergraduate Studies, 13(1), 17-37.

Choi, K. M., Lee, Y. S., \& Park, Y. S. (2015). What CDM can tell about what students have learned: An analysis of TIMSS eighth grade mathematics. Eurasia Journal of Mathematics, Science \& Technology Education, 11(6), 1563-1577.

Cohen, L., Manion, L., \& Morrison, K. (2000). Research methods in education. London: Routledge Falmer.

de la Torre, J. (2011). The generalized DINA model framework. Psychometrika, 76(2), 179199.

Delice, A. ve Sevimli, E. (2010). Matematik öğretmeni adaylarının belirli integral konusunda kullanılan temsiller ile işlemsel ve kavramsal bilgi düzeyleri. Gaziantep Üniversitesi Sosyal Bilimler Dergisi, 9(3), 581-605. 
Delice, A. ve Sevimli, E. (2011). İntegral kavramının öğretiminde konu sıralamasının kavram imgeleri bağlamında incelenmesi; belirli ve belirsiz integraller. Pamukkale Üniversitesi Eğitim Fakültesi Dergisi, 30(30), 51-62.

DiBello, L. V., Stout, W. F., \& Roussos, L. A. (1995). Unified cognitive/psychometric diagnostic assessment likelihood-based classification techniques. In P. Nichols, S. Chipman, \& R. Brennan (Eds.), Cognitively diagnostic assessment (pp. 361-390). Hillsdale, NJ: Lawrence Erlbaum.

Dogan, E., \& Tatsuoka, K. (2008). An international comparison using a diagnostic testing model: Turkish students' profile of mathematical skills on TIMSS-R. Educational Studies in Mathematics, 68(3), 263-272.

Durmuş, S. (2004). Matematikte öğrenme güçlüklerinin saptanması üzerine bir çalışma. Kastamonu Ĕ̈itim Dergisi, 12(1), 125-128.

Dündar, S. ve Yılmaz, Y. (2015). Matematik öğretmen adayları hangi gösterim biçiminde daha başarılıdır? İntegral Örneği. Türk Bilgisayar ve Matematik Eğitimi Dergisi, 6(3), 418445.

Ergene, Ö. (2014). İntegral hacim problemleri çözüm sürecindeki bireysel ilişkilerin uygulama topluluğu bağlamında incelenmesi. Yayımlanmamış Yüksek Lisans Tezi, Marmara Üniversitesi, İstanbul.

Ergene, Ö. (2019). Matematik öğretmeni adaylarının Riemann toplamlarını kullanarak modelleme yoluyla belirli integrali anlama durumlarının incelenmesi. Yayımlanmamış doktora tezi, Marmara Üniversitesi, İstanbul.

Ersoy, Y. (2002). Matematik okuryazarlığı II: Hedefler, geliştirilecek yetiler ve beceriler. In O. Çelebi, Y. Ersoy \& G. Öner (Eds.), Matematik Etkinlikleri Sempozyumu, Ankara: Matematikçiler Derneği Yayınları.

Ethington, C. A. (1992). Gender differences in a psychological model of mathematics achievement. Journal for Research in Mathematics Education, 23(2), 166-181.

Evans, J. D. (1996). Straightforward statistics for the behavioral sciences. Pacific Grove, CA: Brooks/Cole Publishing.

Ferrini-Mundi, J., \& Graham, K. (1994) Research in calculus learning: Understanding of limits, derivatives and integrals. In J. J. Kaput \& E. Dubinsky (Eds.), Research Issues in Undergraduate mathematics Learning (pp. 31-45). Washington DC: MAA.

Forgası, H. (2005). Gender and mathematics: re-igniting the debate. Mathematics Education Research Journal, 17(1), 1-2. 
Fraenkel, J. R., Wallen, N. E., \& Hyun, H. H. (2012). How to design and evaluate research in education (8th ed.). New York: McGraw Hill.

Ginsburg, H. P. (1989). Children's arithmetic: How they learn it and how you teach it (2nd ed.). Austin, TX: Pro-ED.

Grossman, H., \& Grossman, S. H. (1994). Gender issues in education. Needham Heights, MA: Allyn \& Bacon.

Gürbüz, R., Toprak, Z., Yapıcı, H. ve Doğan, S. (2011). Ortaöğretim matematik müfredatında zor olarak algılanan konular ve bunların nedenleri. Gaziantep Üniversitesi Sosyal Bilimler Dergisi, 10(4), 1311-1323.

Hartz, S. (2002). A Bayesian framework for the unified model for assessing cognitive abilities: Blending theory with practice. Yayımlanmamış doktora tezi, University of Illinois, Urbana-Champaign.

Henson, R., Templin, J., \& Willse, J. (2009). Defining a family of cognitive diagnosis models using log-linear models with latent variables. Psychometrika, 74(2), 191-210.

Hiebert, J., \& Carpenter, T. P. (1992). Learning and teaching with understanding. In D. A. Grouns (Ed.), Handbook of Research on Mathematics Teaching and Learning (pp. 6597). New York: Macmillan.

Hiebert, J., \& Lefevre, P. (1986). Conceptual and procedural knowledge for teaching on student achieviement. In J. Hiebert (Ed.), Conceptual and Procedural Knowledge: The Case of Mathematics (pp. 1-27). Hillsdale, NJ: Erlbaum.

Im, S., \& Park, H. J. (2010). A comparison of US and Korean students' mathematics skills using a cognitive diagnostic testing method: Linkage to instruction. Educational Research and Evaluation, 16(3), 287-301.

Junker, B. W., \& Sijtsma, K. (2001). Cognitive assessment models with few assumptions, and connections with nonparametric item response theory. Applied Psychological Measurement, 25(3), 258-272.

Karabey, B. (2011). Değişen ÖSS sisteminin öğrencilerin integral konusundaki başarıları üzerinde etkisi. Dokuz Eylül Üniversitesi Buca Eğitim Fakültesi Dergisi, 29(2011), 192202.

Karasar, N. (2014). Bilimsel araştırma yöntemi (26. Baskı). Ankara: Nobel Akademik Yayınc1lik. 
Konyalığlu, Tortumlu, Kaplan, Işık ve Hızarcı (2011). Matematik öğretmen adaylarının integral kavramını kavramsal anlamaları üzerine. Bayburt Üniversitesi Ĕ̆itim Fakültesi Dergisi, 6(I-II), 1-8.

Kuzu, O. (2017). Matematik ve Fen Bilgisi öğretmen adaylarının integral konusundaki kazanımlarının incelenmesi. Kırşehir Eğitim Fakültesi Dergisi, 18(3), 948-970.

Kuzu, O. (2020a) Preservice mathematics teachers' competencies in the process of transformation between representations for the concept of limit: A qualitative study. Pegem Journal of Education and Instruction, 10(4), 1037-1066.

Kuzu, O. (2020b). Preservice mathematics teachers' representation transformation competence levels in the process of solving limit problems. Acta Didactica Napocensia, 13(2), 30655.

Kuzu, O. ve Arıcan, M. (2020). Matematik öğretmeni adaylarının istatistik ve olasılık konularındaki yeterliklerinin çeşitli değişkenler açısından incelenmesi. Eğitimde ve Psikolojide Ölçme ve Değerlendirme Dergisi, 11(1), 13-26.

Kuzu, O., Çil, O. ve Şimşek, A. S. (2018). 2018 Matematik Dersi Öğretim Programı Kazanımlarının Revize Edilmiş Bloom Taksonomisine Göre İncelenmesi. Erzincan Üniversitesi Ĕ̈itim Fakültesi Dergisi, 21(3), 129-147.

Lawshe, C. H. (1975). A quantitative approach to content validity. Personnel Psychology, 28, 563-575.

Lee, Y. S., Park, Y. S., \& Taylan, D. (2011). A cognitive diagnostic modeling of attribute mastery in Massachusetts, Minnesota, and the US national sample using the TIMSS 2007. International Journal of Testing, 11(2), 144-177.

Leighton, J. P., \& Gierl, M. J. (2007). Why cognitive diagnostic assessment? In J. P. Leighton \& M. J. Gierl (Eds.), Cognitive diagnostic assessment for education (pp. 3-18). Cambridge: Cambridge University Press.

Lloyd, J. E. V., Walsh, J., \& Yailagh, M. S. (2005). Sex differences in performance attributions, self-efficacy, and achievement in mathematics: if I'm so smart, why don't I know it? Canadian Journal of Education, 28 (3), 384-408.

MEB (2018). Ortaöğretim matematik dersi (9, 10, 11 ve 12. sinıflar) ögretim programı. Milli Eğitim Bakanlığı, Ankara.

Nichols, P. D., Chipman, S. F., \& Brennan, R. L. (Eds.), (2012). Cognitively diagnostic assessment. Hillsdale, NJ: Erlbaum. 
Orton, A. (1983). Student's understanding of integration. Educational Studies in Mathematics, 14(1), 1-18.

Öçal, M. F. (2017). The effect of geogebra on students' conceptual and procedural knowledge: the case of applications of derivative. Higher Education Studies, 7(2), 67-78.

ÖSYM (2019). Öğretmenlik alan bilgisi testi (ÖABT): Test konularının dağ1lımı ve yeni $\begin{array}{llll}\text { eklenen } & \text { alanlara } & \text { ait } & \text { örnek }\end{array}$ https://dokuman.osym.gov.tr/pdfdokuman/2019/KPSS/OABT/konudagilim0102019.pdf adresinden 12.08.2020 tarihinde alınmıştır.

Özden, B. ve Yenice, N. (2016). Fen bilgisi öğretmen adaylarının bilimsel kanun ve teori kavramlarına yönelik görüşleri: Nitel bir durum çalışması. İlköğretim Online, 15(4), 1090-1113.

Patton, M. Q. (2002). Qualitative research and evaluation methods. Thousand Oaks, CA: Sage. R Core Team. (2017). R: A language and environment for statistical computing. Vienna, Austria: R Foundation for Statistical Computing. http://www.R-project.org/ adresinden 21.07.2020 tarihinde alınmıştır.

Ramdani, Y., Rohaeni, O., \& Wachidah, L. (2019). Competency indicator of integral calculus in scientific debate strategies based on student education background. Journal of Physics: Conference Series 1157(3), 1-7.

Rasslan, S., \& Tall, D. (2002). Definitions and images for the definite integral concept. In A. Cockburn \& E. Nardi (Eds.), Proceedings of the 26th Psychology of Mathematics Education (pp. 89-96). Norwich, United Kingdom.

Ravand, H., \& Robitzsch, A. (2015). Cognitive diagnostic modeling using R. Practical Assessment, Research \& Evaluation, 20(11), 1-12.

Reason, M. (2003). Relational, instrumental and creative understanding. Mathematics Teaching, 184, 5-7.

Rittle-Johnson, B., Siegler, R. S., \& Alibali, M. W. (2001). Developing conceptual understanding and procedural skill in mathematics: An iterative process. Journal of educational psychology, 93(2), 346-362.

Rittle-Johnson, B., \& Schneider, M. (2015). Developing conceptual and procedural knowledge of mathematics. In R. Cohen Kadosh \& A. Dowker (Eds.), Oxford handbook of numerical cognition (pp. 1118-1134). Oxford, UK: Oxford Universty Press. 
Rösken, B., \& Rolka, K. (2007). Integrating intuition: The role of concept image and concept definition for students' learning of integral. The Montana Mathematics Enthusiast, 3, 181-204.

Rupp, A., \& Templin, J. (2008). Effects of Q-matrix misspecification on parameter estimates and misclassification rates in the DINA model. Educational and Psychological Measurement, 68(1), 78-98.

Rupp, A. A., Templin, J. L., \& Henson, R. A. (2010). Diagnostic assessment: Theory, methods, and applications. New York, NY: Guilford Press.

Russell, R.L., \& Ginsburg, H.P. (1984). Cognitive analysis of children's mathematical difficulties. Cognition and Instruction, 1(2), 217-244.

Satorra, A., \& Bentler, P. M. (2010). Ensuring positiveness of the scaled difference chi-square test statistic. Psychometrika, 75(2), 243-248.

Sen, S., \& Arican, M. (2015). A diagnostic comparison of Turkish and Korean students' mathematics performances on the TIMSS 2011 assessment. Journal of Measurement and Evaluation in Education and Psychology, 6(2), 238-253.

Sevimli, E. (2013). Bilgisayar cebiri sistemi destekli öğretimin farklı düşünme yapısındaki ögrencilerin integral konusundaki temsil dönüşüm süreçlerine etkisi. Yayımlanmamış doktora tezi, Marmara Üniversitesi, İstanbul.

Sevimli, E. (2009). Matematik öğretmen adaylarının belirli integral konusundaki temsil tercihlerinin uzamsal yetenek ve akademik başarı bağlamında incelenmesi. Yayımlanmamış yüksek lisans tezi, Marmara Üniversitesi, İstanbul.

Smith, D. D., \& Rivera, D. (1991). Mathematics. In B. Wong (Ed.), Learning about Learning Disabilities (pp. 346-375). Orlando, FL: Academic Press.

Skemp, R. R. (1976). Relational understanding and instrumental understanding. Mathematics Teaching, 77(1), 20-26.

Soylu, Y. ve Soylu, C. (2006). Matematik derslerinde başarıya giden yolda problem çözmenin rolü. İnönü Üniversitesi Eğitim Fakültesi Dergisi, 7(11), 97-111.

Star, J. R. (2005). Reconceptualizing procedural knowledge. Journal for research in mathematics education, 36(5), 404-411.

Star, J. R. (2007). Foregrounding procedural knowledge. Journal for Research in Mathematics Education, 38(2), 132-135. 
Tall, D., \& Vinner, S. (1981). Concept image and concept definition in mathematics with particular reference to limits and continuity. Educational Studies in Mathematics, 12(2), 151-169.

Tatar, E., Okur, M. ve Tuna, A. (2008). Ortaöğretim matematiğinde öğrenme güçlüklerinin saptanmasına yönelik bir çalışma. Kastamonu Eğitim Dergisi, 16(2), 507-516.

Tatsuoka, K. (1985). A probabilistic model for diagnosing misconceptions by the pattern classification approach. Journal of Educational Statistics, 10(1), 55-73.

Templin, J., \& Bradshaw, L. (2013). Measuring the reliability of diagnostic classification model examinee estimates. Journal of Classification, 30(2), 251-275.

Templin, J., \& Henson, R. (2006). Measurement of psychological disorders using cognitive diagnosis models. Psychological Methods, 11(3), 287-305.

Veneziano L., \& Hooper J. (1997). A method for quantifying content validity of health-related questionnaires. American Journal of Health Behavior, 21(1), 67-70.

Vinner, S. (1991). The role of definitions in the teaching and learning of mathematics. In D. Tall (Ed.), Advanced mathematical thinking. Dordrecht: Kluwer Academic.

von Davier, M. (2005). A general diagnostic model applied to language testing data (ETS Research Report No. RR-05-16). Princeton, NJ: Educational Testing Service.

Vukovic, R. K., \& Siegel, L. S. (2010). Academic and cognitive characteristics of persistent mathematics difficulty from first through fourth grade. Learning Disabilities Research \& Practice, 25(1), 25-38

Wagner, J. F. (2016). Analyzing students' interpretations of the definite integral as concept projections. In T. Fukawa-Connelly, N. Infante, M. Wawro \& S. Brown (Eds.), Proceedings of the 19th Annual Conference on Research in Undergraduate Mathematics Education (pp. 1385-1392). Pittsburgh, PA.

Werner, C., \& Schermelleh-Engel, K. (2010). Deciding between competing models: Chisquare difference tests. In Introduction to structural equation modeling with LISREL (pp. 1-3). Goethe University, Frankfurt.

Yanık, B. (2016). Kavramsal ve işlemsel anlama. İçinde E. Bingölbali, S. Arslan \& İ.Ö. Zembat (Eds.), Matematik ĕgitiminde teoriler (ss. 101-116). Ankara: Pegem Akademi Yayınc1lık. Yetkin, E. (2003). Student difficulties in learning elementary mathematics. ERIC Digest.

YÖK (2007). Eğitim fakültesi öğretmen yetiştirme lisans programları. https://www.yok.gov.tr/Documents/Yayinlar/Yayinlarimiz/egitim-fakultesi-ogretmenyetistirme-lisans-programlari.pdf adresinden 15 Nisan 2020 tarihinde alınmıştır. 
YYÜ Eğitim Fakültesi Dergisi (YYU Journal of Education Faculty), 2021; 18(1)249-283,http://efdergi.yyu.edu.tr,

doi:10.33711/yyuefd.859592

YÖK
Araştırma Makalesi
(2018). Yeni öğretmen yetiştirme lisans programları.

ISSN: 1305-2020

https://www.yok.gov.tr/kurumsal/idari-birimler/egitim-ogretim-dairesi/yeni-ogretmenyetistirme-lisans-programlari adresinden 15 Nisan 2020 tarihinde alınmıştır.

Zakaria, E., \& Salleh, T. S. (2015). Using technology in learning integral calculus. Mediterranean Journal of Social Sciences, 6(5), 144-148. 


\section{Summary}

\section{Statement of Problem}

The analysis science, in which theorems and rules are explained in an interrogative manner and based on logic and set theory (Sevimli, 2013), is in relation to almost every branch of mathematics and forms the basis of many disciplines (Ergene, 2019). It is known that the integral concept, which is among the basic concepts of analysis science, is among the most difficult concepts to learn, teach and make sense of. In order to provide full meaning, the conceptual and procedural knowledge in the nature of comprehension must be in a balanced connection with each other. Therefore, it is important to know to what extent the conceptual and procedural knowledge attributes regarding the integral concept are attained, in terms of providing cognitive feedback to educators about these attributes and providing more detailed information about the cognitive strengths and weaknesses of the preservice teachers. In this context, the probability of preservice mathematics and science teachers having attributes at the conceptual and procedural knowledge levels regarding the integral concept were calculated using the log-linear diagnostic model (LCDM), which is one of the cognitive diagnosis models that allows more reliable and more detailed evaluation. This model provides more reliable and more detailed information than research based on a single score such as mean or total (Nichols et. al., 2012; Leighton \& Gierl, 2007). Moreover, in the analysis process, while calculating the probability of candidates having competencies, the probability of correct answers to the items by those who do not have any qualifications is also taken into account (Kuzu \& Arican, 2020). All these have been the reason why LCDM is preferred in this study.

\section{Method}

This study was designed with LCDM, one of the cognitive diagnosis models, in order to determine the critical attributes required for understanding the integral concept and to investigate the probability of preservice teachers having these attributes. In this context, the "Integral Attribute Research Test (IART)", which measures four critical attributes (A1: Explains the concept of definite and indefinite integrals; A2: Knows the definite and indefinite integration methods; A3: Calculates indefinite integrals; A4: Makes applications using definite integrals) was prepared and administered to a total of 190 preservice mathematics and science teachers in the 2018-2019 academic year. Test consists of 25 multiple-choice questions. Moreover, it was determined that this test, which has a high item-attribute discrimination indices, measures each attributes with $.99, .98, .99$, and .95 reliability respectively. With the help of Mplus 6.12, the probabilities of preservice teachers having attributes for understanding 
the integral concept were calculated and the values obtained were transferred to the SPSS program together with their gender and departments. Whether the probability of preservice teachers having attributes on integral differs according to the department and gender with the Mann-Whitney U test according to the grade levels with the Kruskal Wallis-H test. Moreover, it was investigated for the relationship between the probabilities of preservice teachers having attributes by using Spearman Correlation test.

\section{Findings}

In this section, it was presented in detail the process of preparing of IART accordance with the LCDM and investigating the probabilities of preservice teachers having attributes on integral concept. First of all, Expert opinions were got for attribute measured by test items and, with the Lawshe $(1975)$ technique $\left(\left(N_{\text {measuring }} /\left(N_{\text {total }} / 2\right)\right)-1\right)$, it was determined each item measured which attribute or attributes. For the distribution of these items that measure four critical attributes, a Q-matrix (Table 2) was created and the probability of each preservice teacher having the relevant attribute individually was calculated using the log-linear cognitive diagnostic model with the MPlus 6.12 program. In this process, in order to determine the most suitable LCDM model, MLR (Maximum Likelihood Robust) and log-probability values (Satorra \& Bentler, 2010) were used and the chi-square difference test was performed to compare the three models (Table 3). As a result of the analysis, it was seen that the indexes of smaller fit indices (AIC $=5280.83$; BIC: 5530.85, SSA BIC: 5286.94) emerged with the new model named Model X and the estimated number of parameters was 77, so it was decided to use this new model (Model X).

\section{Conclusion, Discussion and Recommendations}

In this study, it was determined that the attributes of preservice mathematics teachers towards the conceptual knowledge levels were higher than the attributes for the procedural knowledge level. The preservice teachers' high level of concept knowledge attributes will form the basis for the learning of related concepts that they will learn later and will contribute positively to the learning process (Kuzu, 2017). It has been found out that the preservice science teachers' procedural knowledge levels are much higher. Similarlay, in the study conducted by Özden \& Yenice (2016), it was stated that preservice science teachers could not express the theory and laws clearly.

On the other hand, in this study, it was revealed that female preservice teachers concentrated more on conceptual knowledge and had higher knowledge of theory and method than male preservice teachers. It was determined that the procedural knowledge level of male 
preservice teachers were higher. In this study, the probability of having A1 and A2 attributes, in which conceptual knowledge comes to forward, was found to be higher in 2nd grade preservice mathematics teachers and 1st grade preservice science teachers. The main reason for this may be that the integral subject is included in the 2nd grade in the mathematics curriculum and in the 1st grade in the science curriculum. On the other hand, in this study, a statistically significant relationship was observed between all attributes for the probability of preservice mathematics and science teacher having attributes on integral. When the direction of the relationship is examined, it is revealed that a preservice teacher with a high conceptual knowledge of integral has low procedural knowledge, and a preservice teacher with high procedural knowledge has low conceptual knowledge. However, it was stated that the conceptual knowledge formed by the internalization and association of mathematical knowledge makes procedural knowledge meaningful (Hiebert \& Lefevre, 1986), both types of knowledge are needed in mathematics teaching and one is not more important than the other (Ersoy, 2002).

Knowing the extent to which the attributes in the conceptual and procedural knowledge levels are attained enables diagnostic evaluations for understanding the integral issue and determining its strengths and weaknesses. Establishing a relationship and balance between conceptual and procedural knowledge provides opportunity for the subject to be fully internalized. Therefore, by concretizing the abstract integral subject, it can be provided to increase the attributes for procedural knowledge. In addition, course contents can be enriched thanks to various visual and technological processes that allow spatial visualization and digital modeling with real life applications of integrals in the teaching process.

\section{Etik Kurul Kararı}

Kırşehir Ahi Evran Üniversitesi Sosyal ve Beşeri Bilimleri Yayın Etik Kurulu'nun, 01/07/2020 tarih ve 2020/02 sayılı kararı gereği çalışma açısından Sosyal ve Beşeri Etik Kuralları ve İlkeleri çerçevesinde herhangi bir sakınca olmadığına karar verilmiştir. 

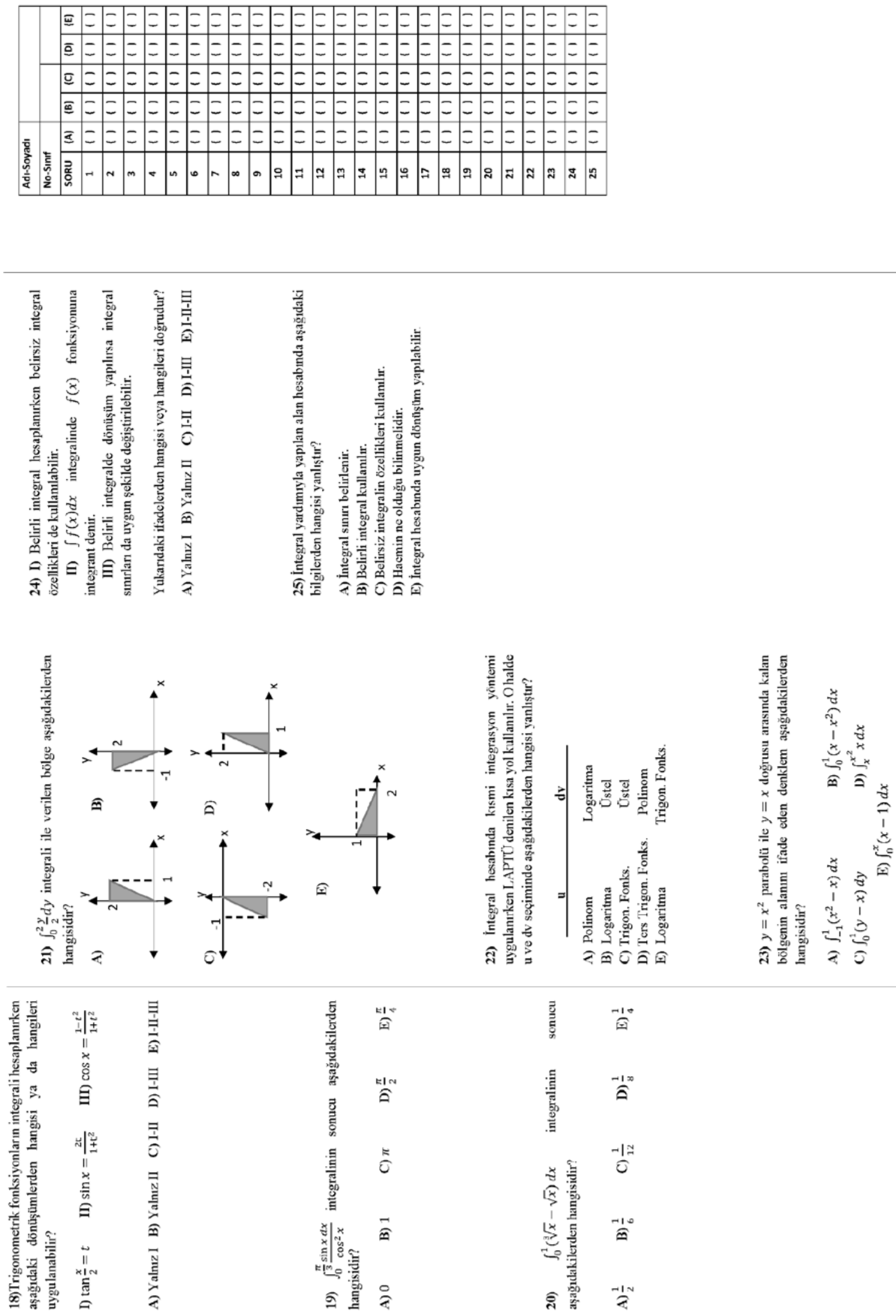